\title{
Incorporation of oil into diatom aggregates
}

\author{
U. Passow ${ }^{1,2, *}{ }^{,}$J. Sweet ${ }^{1}$, S. Francis ${ }^{1}$, C. Xu ${ }^{3}$, A. L. Dissanayake ${ }^{4}$, Y.-Y. Lin ${ }^{5}$, \\ P. H. Santschi ${ }^{3}$, A. Quigg ${ }^{3}$ \\ ${ }^{1}$ University of California Santa Barbara, Santa Barbara, CA 93106, USA \\ ${ }^{2}$ Memorial University, St. John's, NL A1M 5S7, Canada \\ ${ }^{3}$ Texas A\&M University at Galveston, Galveston, TX 77554, USA \\ ${ }^{4}$ RPS Ocean Science, South Kingstown, RI 02879, USA \\ ${ }^{5}$ University of North Carolina, Chapel Hill, NC 27599, USA
}

\begin{abstract}
Rolling table experiments were conducted to investigate the incorporation of 2 types of dispersed oil into diatom aggregates. The goal was to provide specific input parameters for aggregation models that predict the transport of oil to depth via marine snow-sized aggregates $(>0.5 \mathrm{~mm})$. The amount of oil incorporated into aggregates is a function of both aggregated biomass and dispersed oil concentration. The maximum carrying capacity of diatom aggregates for dispersed oil likely lies at $\sim 40 \%$ of the aggregated organic carbon. These data allow estimates of the amount of oil routed via the aggregation pathway. Furthermore, the concentrations of transparent exopolymer particles (TEP) and the composition of EDTA-extracted extracellular polymeric substances (EPS) were tested as generally valid proxies for stickiness, which is a critical value in aggregation models. TEP and EDTA-extractable EPS were correlated with each other, but aggregation success was not readily predictable from these measurements. The large chemical heterogeneity of TEP and EPS likely obscures a generally valid relationship. Additionally, we found that, contrary to expectations, the sinking velocity of oil-containing aggregates was not decreased, but slightly increased compared to their non-oil-containing counterparts. Tighter packaging of cells due to the oil likely causes this effect. Sinking velocity is an important parameter in aggregation-sedimentation models, as it determines the time required for aggregates to reach the seafloor and thus the potential for flux attenuation. Transport of oil to the seafloor exposes benthic organisms, and those feeding on them, to substances that potentially have negative effects on organisms and ecosystems.
\end{abstract}

KEY WORDS: Diatom-oil interaction · Oil distribution · Aggregation of oil · Sedimentation of oil

\section{INTRODUCTION}

When spilled into the oceans, liquid oil compounds form a layer of oil residues at the water-atmosphere interface, dissolve in water (soluble compounds) or exist as dispersed droplets, depending on their physicochemical properties and environmental conditions (wind, wave action, presence of dispersants). Sorption of dissolved oil compounds to marine particles, as well as the incorporation of oil droplets into marine snow, or the coagulation of oil droplets with sediment/mineral particles, leads to oil-particle associations. Whereas dissolved or dispersed oil compounds will move with water currents only, such

${ }^{*}$ Corresponding author: uta.passow@lifesci.ucsb.edu oil-particle associations may additionally sink, transporting oil to depth.

Significant sedimentation of hydrocarbons in association with phytoplankton was observed in mesocosm studies performed in the 1970s and 1980s (Lee \& Anderson 1977, Lee et al. 1978, 1985). Initially, sorption of oil compounds to cells and active uptake of specific compounds were considered the main causes (Lee et al. 1978), but the association of oil droplets with phytoplankton, bacteria, their polysaccharide exudates and detritus was also described (Lee et al. 1985). Small oil droplets were trapped within an immobilizing organic matrix of large aggregates that included diatoms, bacteria and detri-

() The authors 2019. Open Access under Creative Commons by Attribution Licence. Use, distribution and reproduction are unrestricted. Authors and original publication must be credited. 
tus. However, such incorporation of oil into marine snow was rarely, if ever, observed in situ during those years, when large oil spills into marine waters were mostly coastal. In such environments, the primary cause for the sedimentation of oil was thought to be the associations between oil and fine sediment or mineral particles. In the presence of such suspended, lithogenic particles, small oil droplets are coated with micro-sized mineral particles, forming $\sim 100 \mu \mathrm{m}$ associations (Zhao et al. 2016, 2017). A rich literature exists on oil-mineral aggregates (OMAs), oil-sediment aggregations (OSAs) or oil-particle aggregations (OPAs) as they are often variously called, and their impact on the fate of spilled oil (see reviews in Lee 2002, Lee et al. 2008, Gong et al. 2014). Here, we use the term OPA when referring to such oil-sediment associations.

The Deepwater Horizon (DwH) oil spill in the Gulf of Mexico in 2010 was the first large spill in deep water, where suspended sediment concentrations are commonly too low to lead to significant formation of OPAs. In the direct vicinity of the leak, however, the deposition of drilling mud during the top-kill operation led to the sedimentation of OPAs. Large amounts of oil also sank in association with marine snow-sized $(>0.5 \mathrm{~mm})$ phytoplankton aggregates and were deposited on the seafloor (Passow \& Ziervogel 2016, Yan et al. 2016, Romero et al. 2017). Oil compounds analyzed in sediments have been found associated with phytoplankton, especially diatoms, also corroborating the association between diatoms and oil compounds as well as the transport of oil to the seafloor (Kowalewska 1999, Lubecki \& Kowalewska 2010, Parsons et al. 2014, Romero et al. 2015).

Aggregation and subsequent sedimentation during the declining phase of a bloom are part of the lifecycle of coastal diatoms (Smetacek 1985, Passow et al. 1994). Diatom aggregates efficiently collect and sediment fine clay or quartz particles which are otherwise too small to sediment individually (Hamm 2002), with the result that such sedimentation events sweep the water column 'clean', collecting nonsinking particles in their path (Passow 2004). Consequently, it should not have been surprising that phytoplankton aggregates trap and transport dispersed oil droplets to depth as well. Nevertheless, the sedimentation of a significant portion of the spilled oil to the seafloor during and after the DwH accident (Valentine et al. 2014, Larson et al. 2018) was unexpected (Daly et al. 2016).

The fate of spilled oil and the consequences for marine ecosystems differ appreciably depending on its distribution pathways, e.g. via water motion (currents, tides) or via gravitational settling (Daly et al. 2016). Different ecosystems are affected to varying extents depending on their exposure to oil (FrenchMcCay et al. 2016). Oil transformation and degradation rates vary if oil (1) sinks due to its association with particles, versus oil that (2) is neutrally buoyant and carried with surface currents towards shorelines or oil that is (3) dispersed into pelagic waters. In responding to an oil spill, it is thus extremely important to understand which specific distribution pathway(s) are likely to become important so that damage to the environment can be minimized and response efforts can be optimized.

Models that predict oil distribution and fate in the ocean can aid in the evaluation of different response options available during accidental spills as well as in assessing the long-term damage to the ecosystem and environment (North et al. 2015). They include shortterm, operational oil transport and fate models such as GNOME (General NOAA Operational Modeling Environment), CDOG (Comprehensive Deepwater Oil and Gas Blowout Model), OILMAP and TAMOC (Texas A\&M Oilspill Calculator) (Spaulding et al. 1992, Beegle-Krause 2001, Zheng et al. 2003, Gros et al. 2017, Dissanayake et al. 2018b) and long-term oil fate and transport models such as SIMAP (Integrated Oil Spill Impact Oil System) (French-McCay et al. 2015) and OSCAR (Oil Spill Contingency and Response) (Reed et al. 2000). Particle aggregation models coupled with these oil fate and transport models will help in predicting the probability of aggregation and sorption of oil to marine particles and quantitatively estimate oil sedimentation (Zhao et al. 2016, Dissanayake et al. 2018a, Francis \& Passow unpubl. data). However, these models are still in the early development stages and require a better understanding of the main driving mechanisms of oil-particle interactions and aggregation processes, as well as the relevant input parameters in order to make accurate predictions (Dissanayake et al. 2018b, Francis \& Passow unpubl. data).

The experiments conducted here were designed to provide data and the accompanying insights needed to develop realistic aggregation models that can forecast the potential of oil residues to be captured into detrital and phytoplankton aggregates that sink. Models, based on coagulation theory, that predict the formation of phytoplankton aggregates are well-developed (Jackson 1990, Kiørboe et al. 1994, Burd \& Jackson 2009), but need to be expanded to include the presence of oil. In order to facilitate this expansion, 3 hypotheses were tested as part of our experimental 
work: (1) the amount of oil incorporated into aggregates is a function of oil concentration in the surrounding seawater. Estimates of the amount of oil incorporated into sinking aggregates are needed to determine the total amount of oil removed from the water and transported towards the seafloor. (2) The quantity and quality of extracellular polymeric substances (EPS) can predict the likelihood of successful collisions, e.g. the probability that particles remain attached upon collision, because these substances provide the required stickiness, or 'glue', for aggregation. Arguably, stickiness is the least well-defined parameter in coagulation models, and the presence of oil may change average stickiness. Improving estimates of the average stickiness of a particle population would greatly improve the reliability of coagulation models. EPS, and especially transparent exopolymer particles (TEP) are thought to drive stickiness of a particle population (Logan et al. 1995, Verdugo \& Santschi 2010), and oil is believed to promote EPS production in many microbes (Quigg et al. 2016). (3) The sinking velocity of an oil-laden aggregate is decreased compared to a similarly sized one without oil because oil is less dense than water. Sinking velocities of oilcontaining aggregates are an important model input when estimating loss due to seafloor deposition. On average, only about $10 \%$ of particulate organic carbon (POC) that sinks out of the euphotic zone reaches $1000 \mathrm{~m}$ depth, the amount being a function of particle sinking velocities and local attenuation rates of aggregates (e.g. due to disaggregation processes, microbial degradation, etc.). Whereas the decay rate of oil by microbes as a function of temperature has been estimated (e.g. see Adcroft et al. 2010), determination of size-specific sinking velocities of aggregates that contain oil are rare (Passow et al. 2012).

Experiments were conducted with a water accommodated fraction of oil (WAF), simulating conditions below the water-oil interface. Aggregation rates are a function of particle concentration, and phytoplankton abundance maxima are most often below the sea surface. Thus, although phytoplankton aggregation events may at times be at the sea surface and thus include oil from slicks, it is much more likely that aggregating diatoms will trap dissolved and dispersed oil that is below the sea surface. The experiments described here thus focused on simulating oil incorporation below the water-atmosphere interface. An earlier set of experiments focused on oil incorporation into aggregates forming in the presence of an oil slick at the surface (Passow 2016). Experiments were conducted with 2 different oils because oil characteristics likely impact incorpora- tion of oil into aggregates. Surrogate oil from the DwH spill in the Gulf of Mexico in 2010 (Macondo oil) and the oil spilled in the 2015 pipeline accident near Refugio Beach, Santa Barbara County, California, referred to as Refugio oil, were used.

A total of 5 roller tank experiments were conducted to investigate the aggregation of a variety of diatom species and the incorporation of oil into the aggregates (Macondo or Refugio oil; 1\% vol:vol). Roller tank experiments are an established method for simulating the formation and sinking of aggregates (Passow \& De La Rocha 2006, Ploug et al. 2010, Passow 2016). All experiments were conducted in the dark, simulating the aggregation and settling phase but not the growth phase of phytoplankton. The aggregation of cells and incorporation of oil into aggregates, the production of exudates and the sinking velocities of aggregates were investigated to address the 3 hypotheses detailed above.

\section{MATERIALS AND METHODS}

\subsection{Experimental setup and sample collection}

Five roller tank experiments were conducted to investigate the direct impacts of the WAF on the aggregation of diatoms (Table 1). Roller tanks allow for the formation and continuous sinking of aggregates (without collisions with container walls) once solid body rotation is established (Ploug et al. 2010). Each experiment consisted of a different diatom species exposed to a control and to WAF treatments. Table 1 details initial experimental conditions and species characteristics. Experimental temperatures reflected growth temperatures of the species, and experiments were terminated as soon as aggregates formed. The $\mathrm{WAF}_{\mathrm{Mac}}$ and $\mathrm{WAF}_{\text {Ref }}$ were prepared with Macondo surrogate oil (Marlin Platform, Dorado source oil; $\left.0.865 \mathrm{~g} \mathrm{ml}^{-1}\right)$ and Refugio Beach oil $\left(0.946 \mathrm{~g} \mathrm{ml}^{-1}\right)$, respectively. Dense cultures in late exponential/early stationary phase were mixed with WAF or, in case of the control, with pasteurized, oil-free filtered seawater, prepared identically to WAF, except that no oil was added. The seawater, collected from the University of California Santa Barbara (UCSB) seawater system, originates from $800 \mathrm{~m}$ off-shore and $18 \mathrm{~m}$ depth and passes through a series of gravity sand filters.

The general setup was the same in all experiments. Roller tanks were filled bubble-free and incubated in the dark on roller tables at the respective growth temperatures of the cultures (Table 1). Low white light was used during the brief observation periods 


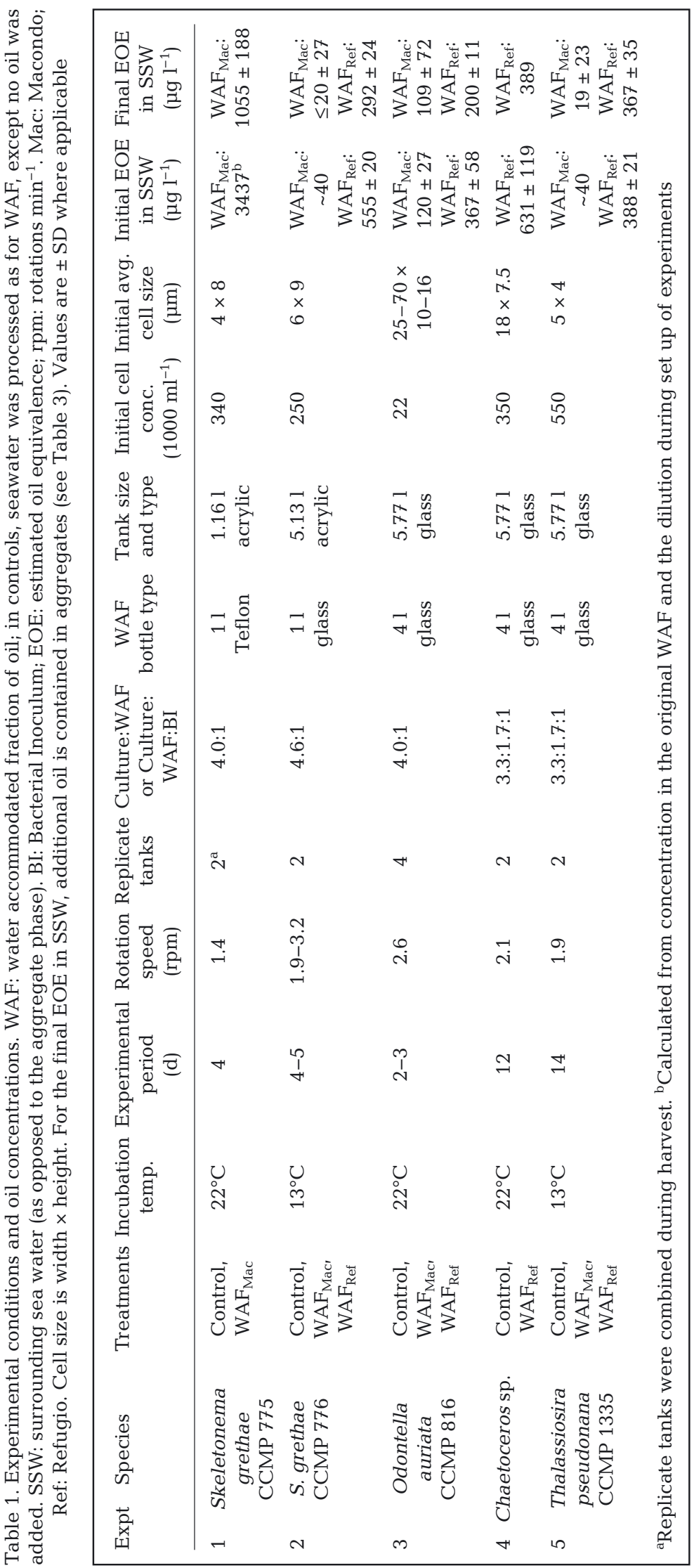

and harvest of Expts 1 and 2, and low green light was used at these times in Expts 3, 4 and 5. Some light (just enough to see) was needed to allow monitoring of cultures and handling of samples, but had no major impact on phytoplankton growth. Although diatom cultures were kept as bacteria-free as possible, and all added WAF and seawater were pasteurized, some bacteria originating from the algae cultures were presumably present in Expts 1 to 3. In Expts 4 and 5, a natural bacteria community was added. Sampling for Expt 3 was the most comprehensive, with 4 replicate tanks treatment ${ }^{-1}$, whereas Expts $1,2,4$ and 5 each involved duplicate tanks for each treatment.

Tanks were harvested after 3-14 d (Table 1), when marine snow-sized aggregates had formed and did not visually change from day to day. For logistical reasons, the 2nd replicate or the 3rd and 4th replicates of each treatment were harvested $1 \mathrm{~d}$ later in Expts 2 and 3, respectively. After careful removal of tanks from rolling tables, aggregates $>1 \mathrm{~mm}$ (visually discernable) were manually collected and analyzed. This fraction is called the aggregate phase (Agg). Collection techniques for aggregates depended on aggregate size and stability. Individual intact aggregates were collected with a cut-off pipette; a known discrete number of aggregates were collected via syringe; or, at times, aggregated material could only be collected in bulk, without associating aggregate numbers with the collected aggregate slurry, because aggregates were too abundant or too fragile for individual collection. After all aggregates were removed, the remainder of the material was mixed and subsampled. This fraction that contained aggregates $<1 \mathrm{~mm}$ and un-aggregated cells is called the surrounding seawater (SSW) fraction. Sampling of aggregates inadvertently also collected some SSW. A correction for this is only possible when the total aggregate volume, distinct from the collected aggregate slurry volume, can be determined. However, particle concentrations in aggregates were so high compared to those in SSW that this intrinsic sampling error was negligible. 
Particulate $(>0.4 \mu \mathrm{m})$ and dissolved $(<0.4 \mu \mathrm{m})$ substances were analyzed in the SSW fraction, whereas the Agg fraction was only analyzed for particulates, with the exception of the estimated oil equivalent (EOE), which was, when possible, also analyzed in the aggregate fraction. Functionally, oil droplets were part of the particulate phase, as they were collected on filters. Subsamples from each fraction were collected to analyze POC and particulate organic nitrogen (PON), TEP, EDTA-extractable EPS and cell numbers. Results were usually normalized per tank to make Agg and SSW fractions directly comparable with each other and to allow estimates of the fraction of material that was aggregated. When possible (Expts 2, 3 and 5), sinking velocities of individual aggregates were determined as a function of aggregate size.

\subsection{Cultures, WAF and bacterial inoculum}

Cultures of Skeletonema grethae CCMP 775, S. grethae CCMP 776, Odontella aurita CCMP 816, Chaetoceros sp. (isolated November 2014 at $38.7^{\circ} \mathrm{N}$, $123.7^{\circ} \mathrm{W}$ ), and Thalassiosira pseudonana CCMP 1335 , all diatoms, were grown at $70 \mu \mathrm{mol} \mathrm{m}{ }^{-2} \mathrm{~s}^{-1}$ of photosynthetically active radiation (PAR) using modified $\mathrm{f} / 2$ media with reduced macronutrients. Both Skeletonema species and $O$. aurita were isolated from the Gulf of Mexico; Chaetoceros sp. and $T$. pseudonana are cosmopolitan species known to form blooms and aggregate. The seawater for making media came from the UCSB seawater intake and was filtered twice $(0.2 \mu \mathrm{m})$ and then UV-treated for $>30$ min before use to kill microbes. Macronutrients were added to final concentrations of $58.9 \mu \mathrm{M}$ nitrate, $3.6 \mu \mathrm{M}$ phosphate and $53.5 \mu \mathrm{M}$ silicic acid. Trace metals and vitamins were added according to the original f/2 recipe (Guillard 1975). Cultures were grown at 13 or $22^{\circ} \mathrm{C}$ (Table 1) under a $12 \mathrm{~h}$ light:12 h dark cycle and used for experiments in late exponential/early senescent phase. Cultures were monitored via in vivo fluorescence using the aquaPen-C-100 (Qubit) and by cell counts.

To make WAF, filtered seawater was pasteurized at $65^{\circ} \mathrm{C}$ for $4-5 \mathrm{~h}$, and oil was added ( $1 \%$ vol:vol) to a glass (Expts 2 to 5) or Teflon (Expt 1) container making sure a $25 \%$ headspace remained. The oil-water mixture was stirred with a sterile magnetic stir bar so that a small vortex, visible as an indentation at the surface, was created, but avoiding a vortex that visibly pulled oil to the container bottom. Stirring lasted for $24 \mathrm{~h}$ in the dark at room temperature. After a $2 \mathrm{~h}$ resting period, the WAF was harvested from the bottom layer using a bottom spigot (Expts 3, 4 and 5) or Teflon tubing inserted through the interface to the bottom of the container (Expts 1 and 2). The upper oily layer was discarded, and the WAF was mixed with the diatom cultures and the bacteria inoculum, where appropriate (Table 1). Fresh WAF was prepared for each experiment, and experiments were started immediately after WAF preparation. Seawater was treated identically to generate 'controlWAF' for controls, except that no oil was added.

In contrast to the Macondo oil, which is a light oil, the oil spilled at Refugio beach (California) in May 2015 was a heavy pipeline oil stemming from the Monterey Formation (Nelson et al. 2016) and is known for its high adhesiveness (National Academies of Sciences, Engineering, and Medicine 2016). The viscosity of Macondo dead oil at $15^{\circ} \mathrm{C}$ is $7.1 \mathrm{mPa} \mathrm{s}$, and at $30^{\circ} \mathrm{C}$ is $4.5 \mathrm{mPa}$ s (Stout 2015a, Gros et al. 2016, 2017). Live oil viscosity is an order of magnitude lower, at about $0.7 \mathrm{mPa}$ s (Zick 2013, Gros et al. 2016, 2017). Details on Macondo oil properties are readily available (French-McCay et al. 2015, 2016, 2018, Stout 2015b, Gros et al. 2016, 2017). Whereas the Macondo oil is well described, much less is known about the Refugio incident oil, which was a blend of Monterey Formation crude oil (Miocene) from 3 offshore oil platforms in the Santa Barbara Channel (Heritage, Harmony, Hondo). The Refugio incident oil was too viscous to allow reliable density determinations (Chris Reddy pers. comm.). It contains hydrocarbons that range from $\mathrm{C} 5$ to $\mathrm{C} 40$, dominated by $\mathrm{n}$-alkanes. Isoprenoids are abundant $(\mathrm{nC} 17 / \mathrm{Pr}=1.1$ and $\mathrm{nC} 18 / \mathrm{Ph}=0.74)$ and the PAHs are dominated by alkyl-naphthalenes (N0-N4), with average total PAH, TPAH50 $=5052 \pm 109 \mathrm{mg} \mathrm{kg}^{-1}$ and TPAH42 $=4623 \pm 171 \mathrm{mg} \mathrm{kg}^{-1}$ (Stout 2016). Sulfurcontaining PAHs (S-PAHs) are relatively abundant (Nelson et al. 2016). The amount of asphaltene-like material, as determined from the solubility in nonpolar solvents (operationally defined) was $20.0 \pm$ $0.6 \%$ in the Refugio incident oil sample (Chris Reddy pers. comm.), but less than $1.0 \pm 0.1 \%$ in the Macondo oil (Lewan et al. 2014). See Table 2 for some additional comparative analysis between the DwH crude and the crude oil harvested from 2 of the platforms that contributed to the Refugio incident oil mix.

The bacteria inoculum was prepared by collecting raw seawater from in front of the Marine Science Institute, UCSB, and pre-filtering it sequentially through 5.0 and $2.0 \mu \mathrm{m}$ filters. The freshly produced $2.0 \mu \mathrm{m}$ filtrate provided the bacterial inoculum that was added to the tanks in Expts 4 and 5 (Table 1). 


\subsection{Analysis}

\subsubsection{Oil concentration}

Oil concentration was determined as EOE after extraction in dichloromethane (Wade et al. 2011, 2017) using a Trilogy fluorometer with the crude oil module 7200-63, which measures at an excitation wavelength of $365 \mathrm{~nm}$ and emission wavelength of 410-600 nm. At these wavelengths, chlorophyll a (chl a) and accessory pigments, as well as colored dissolved organic matter, may generate artificially elevated values. Measured EOEs were corrected for such interference by subtracting the EOE of the control. The magnitude of this correction varied widely between experiments and treatments, ranging from $<10$ to $>50 \%$ of the total EOE signal. Intercalibration showed good performance, and calibration curves were prepared with the respective oils (Bera et al. 2019). Measured EOE values give an estimate of oil concentration in the water, but no budget calculations were attempted. Replicate EOE measurements in the SSW fractions were at times variable, reflecting the uneven distribution of dispersed oil droplets as described in Wade et al. (2017).

\subsubsection{Determination of $\mathrm{POC}, \mathrm{PON}$ and $\mathrm{PO}^{13} \mathrm{C}$}

Two replicate filters (GF/F) each were analyzed for POC/PON and $\mathrm{PO}^{13} \mathrm{C}$, except for Expt 3, where POC and $\mathrm{PO}^{13} \mathrm{C}$ were assessed from 3 replicate filters each. POC/PON filters were measured in a CEC44 OHA elemental analyzer (control equipment). The $\mathrm{PO}^{13} \mathrm{C}$ signature was determined using a Finnigan Delta Plus Advantage. The $\mathrm{PO}^{13} \mathrm{C}$ data were used to calculate the relative contribution of oil-derived carbon to POC using endmember isotope mass balance calculations (Passow et al. 2017). $\mathrm{PO}^{13} \mathrm{C}$ measurements of the controls revealed that in several of the experiments cells initially continued to take up $\mathrm{CO}_{2}$ although experiments were conducted in near darkness or green light. Those cells became $\mathrm{CO}_{2}$ limited, impacting the $\mathrm{PO}^{13} \mathrm{C}$ signature. The calculations of the fraction of oil incorporated into aggregates were thus based on the $\mathrm{PO}^{13} \mathrm{C}$ signature of the aggregates of the controls, rather than on that of the initial culture value. The fraction of POC in aggregates that was oil was calculated as: $\left(\mathrm{PO}^{13} \mathrm{C}_{\text {WAFagg }}-\right.$ $\left.\mathrm{PO}^{13} \mathrm{C}_{\text {controlagg }}\right) /\left(\mathrm{PO}^{13} \mathrm{C}_{\text {oil }}-\mathrm{PO}^{13} \mathrm{C}_{\text {controlagg }}\right)$, with WAFagg symbolizing the aggregates from the WAF treatments, controlagg the aggregates from the control treatment and oil the ${ }^{13} \mathrm{C}$ signal from the oil used from experiments. Using aggregated POC concentrations, the oil-derived carbon content per aggregate may be calculated. This calculation assumes that the addition of oil did not change the cellular uptake rate of $\mathrm{CO}_{2}$, i.e. that cells in the WAF treatments continued to grow as in the controls. The Macondo surrogate oil used had a $\mathrm{PO}^{13} \mathrm{C}$ signature of $\delta^{13} \mathrm{C}=-27.48 \pm 0.24 \%$, slightly lighter than an earlier batch of surrogate Macondo oil $\left(\delta^{13} \mathrm{C}=-28.09 \%\right.$; Passow 2016); the Refugio oil $\mathrm{PO}^{13} \mathrm{C}$ signature was $\delta^{13} \mathrm{C}=-23.28 \pm 0.14 \%$.

\subsubsection{Diatom cells}

Diatoms were counted (Olympus CX41) in the Agg and SSW fractions of Expts 2 to 5 using a hemocytometer; at least 6 subsamples and 200 cells each were counted per sample. Diatom aggregates in all experiments were fragile enough that gentle shaking of sample vials disaggregated cells and made accurate counts possible.

\subsubsection{TEP concentrations}

TEP concentrations were determined in triplicate in the Agg and SSW fractions using the colorimetric method (Passow \& Alldredge 1995). Samples were filtered onto $0.4 \mu \mathrm{m}$ polycarbonate (Poretics) filters and these were stained with Alcian blue. The results were expressed in gum xanthan equivalents $\left(\mathrm{GX}_{\mathrm{eq}}\right)$ (Passow \& Alldredge 1995) and the carbon content was estimated using an average factor of $0.7 \mu \mathrm{g}$ TEP-

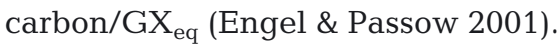

\subsubsection{Composition of attached EDTA-extractable EPS}

The composition of attached EDTA-extractable EPS were determined in the Agg fractions of Expts 1, 2, 3 and 5, and additionally in the SSW fraction of Expt 5. Subsamples of the Agg and SSW fractions were shipped immediately on ice overnight to Galveston to carry out further analyses. Shipping on ice should have kept biodegradation to a minimum, and changes due to aggregation or disaggregation were largely avoided by separating the fractions before shipping. Aggregate slurries of Expts 1, 2 and 3 were filtered onto $0.4 \mu \mathrm{m}$ polycarbonate filters and rinsed 3 times with $5 \mathrm{ml}$ of Milli-Q water $\left(18.2 \mathrm{M} \Omega \mathrm{cm}^{-1}\right)$ to remove salt. The material retained on the filter was 
re-suspended in $25 \mathrm{ml}$ Milli-Q water, the filter discarded and the material freeze-dried. A 1 aliquot sample was used to determine the POC/PON content (for reference purpose) and another was used for the extraction of EPS. In Expt 5 (control and $\mathrm{WAF}_{\mathrm{Mac}}$ treatments), $10 \mathrm{ml}$ of the Agg was filtered onto the $0.4 \mu \mathrm{m}$ polycarbonate membrane, and the whole membrane used for EPS extraction, due to the limited amount of sample that could be weighed for EPS extraction. Additionally, $\sim 0.5 \mathrm{l}$ of SSW from Expt 5 was filtered through a pre-combusted GF/F filter to measure POC and PON concentrations, and another $\sim 0.5 \mathrm{l}$ of SSW was filtered onto a $0.4 \mu \mathrm{m}$ polycarbonate membrane filter for EPS extraction.

To extract EPS, 2-5 mg of the freeze-dried (Expts 1, 2 and 3) or filtered (Expt 5) material was re-suspended in $10 \mathrm{ml}$ of $1 \%$ EDTA solution in pre-combusted $20 \mathrm{ml}$ glass scintillation vials. The EDTA binds $\mathrm{Ca}^{2+}$, thus releasing EPS that is bound via Cabridging, into the solution. A procedural blank was included in order to correct for any interferences from the membrane. The samples were then incubated at $4^{\circ} \mathrm{C}$ for $3 \mathrm{~h}$ on an orbital shaker at $150 \mathrm{rpm}$. After the incubation, the particles were removed using a Flipmate 100 System $(0.45 \mu \mathrm{m}$ PES Environmental Express). Excess EDTA was removed by ultrafiltering the resulting filtrate $(<0.45 \mu \mathrm{m})$ via Amicon Ultra-4 Centrifugal Filter Unit with a $3 \mathrm{kDa}$ cut-off membrane (Millipore). The retentate $(3 \mathrm{kDa}$ $0.45 \mu \mathrm{m})$, which included the ETDA-extracted EPS, was concentrated to $1 \mathrm{ml}$ for further chemical analysis. Aliquots of this extract were used for the determination of organic carbon using a Shimadzu TOC-L analyzer, as well as for analysis of neutral carbohydrate, protein and the uronic acids. Neutral carbohydrate content was determined by the anthrone method (Morris 1948), with glucose as the standard. Uronic acid was estimated by adding sodium borate (75 mM) to concentrated sulfuric acid, heating at $100^{\circ} \mathrm{C}$ for $10 \mathrm{~min}$ and then adding m-hydroxydiphenyl, with glucuronic acid as the standard (Hung \& Santschi 2001). The detection limit was $0.136 \mathrm{mg}$ glucuronic acid eq $\mathrm{l}^{-1}$. Protein content was measured using the Pierce protein assay kit based on a modified bicinchoninic acid assay method (Smith et al. 1985). Bovine serum albumin (BSA) was used as the stan-

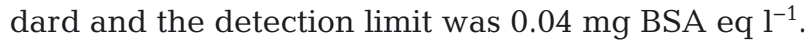

EPS extractions from Agg were normalized to POC in Expts 1 and 2, and based on the volume fraction used for extraction in relation to total volume per tank in Expt 5. Carbon contents of 40, 37 and 53\% were assumed for neutral sugars, uronic acids and proteins, respectively, to calculate the carbon contri- butions of these constituents to EDTA-extractable organic carbon.

\subsubsection{Sinking velocity measurements}

Sinking velocity measurements were conducted following Ploug et al. (2010), using either the settling column method (Expt 2) or the non-destructive orbit method, which involves calculating sinking velocities based on tank rotation speed and the orbital paths of aggregates within the tanks (Expts 3 and 5). In our study, as in the study by Ploug et al. (2010), no systematic difference in sinking velocities between the 2 methods was observed.

\subsubsection{Variability and error estimates}

Working with aggregates is logistically challenging, with the consequence that only small numbers of replicates can be run even though intrinsic variability of measurements of aggregates is high. Combining aggregates into an 'aggregate slurry' is one means of averaging over some of the heterogeneity between individual aggregates. We present averages and standard deviations of replicate tanks and discuss trends in the data, noting if they are statistically significant (at $\mathrm{p}<0.05$ ) or not; $t$-tests were performed using the add-on function in Microsoft Excel. Correlations between variables were calculated in MATLAB using the reduced major axis approach (geometric mean regression, see script: https://www.mbari. org/products/research-software/matlab-scripts-linear-regressions/) when no clear directional causal relationship was present (e.g. EPS-proxies vs. TEP). An asymmetric relationship was expected for the aggregate normalized oil content in aggregates as a function of initial oil concentration in the water (see Fig. 3), but because the error of the independent variable (initial oil concentration in the water) was similar to that of the dependent variable, we calculated both a major axis correlation and a Pearson regression (Smith 2009).

\section{RESULTS AND DISCUSSION}

\subsection{Discussion of experimental design}

Research triggered by the DwH accident showed us that the formation of diatom blooms, if they coincide with an oil spill, can result in massive sedimen- 
tation of the spilled oil to the seafloor (Brooks et al. 2015, Daly et al. 2016, Yan et al. 2016, Larson et al. 2018), because oil compounds are incorporated into the rapidly sinking diatom aggregates as droplets or sorbed to diatoms (Wirth et al. 2018). Experiments described here investigated the potential ability of such diatom blooms to transport oil to depth, with the goal of providing supporting data for models that predict the likelihood that such an event occurs during a specific oil spill. Sedimentation of oil with diatom blooms impacts the distribution pathways of spilled oil and may affect benthic habitats severely (Baguley et al. 2015, Fisher et al. 2016, Washburn et al. 2017, Schwing et al. 2018).

Because aggregate formation and sedimentation is species-specific, we conducted experiments with 5 different diatoms, 3 of which were isolated from the Gulf of Mexico, plus 2 cosmopolitan species. The experiments were designed to mimic the declining phase of a bloom, rather than the growth phase, as the aggregation and sedimentation phase of the bloom are central in determining the potential transport of oil by diatom aggregates. Thus, experiments were conducted in darkness in rolling tanks to inhibit diatom growth, promote aggregate formation and simulate sinking through the deep, dark ocean. Experimental temperatures, cell concentrations and tank rolling speeds were chosen appropriately for each species so as to avoid temperature stress responses and to keep aggregates from hitting the tank walls rather than simulating continuous sinking.
Most of the apparent heterogeneity in experimental conditions is a consequence of biological differences between the 5 species.

\subsection{Oil addition}

Although WAF was prepared using the same oil to water ratio for each experiment, initial EOE concentrations varied between experiments and between oil types, in part because the mixing ratios of WAF and cultures plus bacteria inoculum differed, because of modifications in WAF bottle type and because of differences in oil type (Table 1). By far the highest initial EOE was observed in Expt 1, where $\mathrm{WAF}_{\mathrm{Mac}}$ was prepared in Teflon bottles. In all other experiments, where WAF was prepared in glass bottles, initial oil concentrations were lower. Likely, wall effects in glass bottles reduced oil available for dispersion. Because such glass wall effects are particularly prominent for oil compounds with poor water solubility, a difference in chemical composition between both types of WAF would be expected. Initial oil concentrations in experiments were always significantly higher in the $\mathrm{WAF}_{\text {Ref }}$ treatments (EOE between 367 and $631 \mu \mathrm{g} \mathrm{l}^{-1}$ ) compared to the $\mathrm{WAF}_{\mathrm{Mac}}$ treatments (EOE all $\leq 120 \mu \mathrm{g} \mathrm{l}^{-1}$ ), indicating differences in the natural dispersibility of the 2 types of oil. The observed high dispersibility of the Refugio incident oil was unexpected, as the crude oil from the platforms contributing to the Refugio oil exhibited an

Table 2. Characteristics of the crude oils from the Deepwater Horizon (DwH) riser (ESTS code: 1598.3) and from platforms Harmony (ESTS code: 1953.1) and Heritage (ESTS codes: 1499.1 and 1500.1), which contributed to the Refugio incident oil. Based on 'physiochemical properties of petroleum products-EN' from the environment Canada oil database that is available through the GNOME model oil library (https://github.com/NOAA-ORR-ERD/OilLibrary). API: American Petroleum Institute; GC: gas chromatography; TPH: total petroleum hydrocarbon; TSH: total saturate hydrocarbon; TAH: total aromatic hydrocarbon. Evaporation (E) is expressed as a function of Temperature $\mathrm{T}$ and time $t$, with $\mathrm{A}$ and $\mathrm{B}$ as specific parameters for each oil. Values are \pm SD where applicable

\begin{tabular}{|lccc|}
\hline & $\begin{array}{c}\text { DwH riser } \\
\text { (Gulf of Mexico) }\end{array}$ & $\begin{array}{c}\text { Harmony platform } \\
\text { (Santa Barbara Channel) }\end{array}$ & $\begin{array}{c}\text { Heritage platform } \\
\text { (Santa Barbara Channel) }\end{array}$ \\
\hline Density at $15^{\circ} \mathrm{C}\left(\mathrm{g} \mathrm{ml}^{-1}\right.$ ) & $0.838 \pm 0.000$ & $0.946 \pm 0.000$ & $0.992 \pm 0.000$ and $0.986 \pm 0.000$ \\
API gravity & 36.2 & 17.8 & 11.0 and 11.9 \\
Dyn. viscosity at $15^{\circ} \mathrm{C}\left(\mathrm{mPa} \mathrm{s}^{-1}\right)$ & $7^{\mathrm{a}}$ & $3080 \pm 12$ & $360000 \pm 8600$ \\
Surface tension $15^{\circ} \mathrm{C}(\mathrm{oil}-\mathrm{air})$ & $24.4 \pm 0.7$ & Too viscous & Too viscous \\
Evaporation: $\% \mathrm{E}=(\mathrm{A}+\mathrm{BT})$ ln $t$ & $\mathrm{~A}=4.52 ; \mathrm{B}=0.045$ & $\mathrm{~A}=0.85, \mathrm{~B}=0.045$ & $<10$ \\
Chemical dispersibility (\%) & $75 \pm 5$ & $<10$ & 7.2 and 6.3 \\
with Corexit 9500 & 0.3 & 4.7 & 66 and 63 \\
Sulfur content $(\%)$ & 78 & 64 & 34 and 44 \\
GC-TSH/GC-TPH (\%) & 22 & 36 & $27.2 \pm 0.3$ and $31 \pm 3.0$ \\
GC-TAH/GC-TPH (\%) & $0.3 \pm 0.1$ & $25.0 \pm 0.1$ & \\
Asphaltenes (\%) & & & \\
aFrom Stout (2015a) & & & \\
\hline
\end{tabular}


extremely low dispersibility (Table 2). Initial oil con-

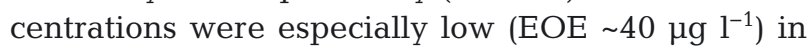
$\mathrm{WAF}_{\mathrm{Mac}}$ treatments of Expts 2 and 5. Oil concentrations declined during all experiments. Besides incorporation into aggregates, attachment of oil to container walls and biodegradation of oil contributed to the decrease in EOE concentration in the water during our experiments, which were conducted in a closed system and in the dark. Final EOE concentrations ranged from $\sim 20$ to $>1000 \mu \mathrm{g} \mathrm{l}^{-1}$ (Table 1). All EOE concentrations were within the ranges reported after the DwH oil spill (e.g. see Wade et al. 2011, S. Francis \& U. Passow unpubl. data).

The composition of oil may change due to processes like evaporation, photochemical and microbial degradation. We did not measure individual oil compounds, but use the terms oil or WAF to represent the concentrations of the oil residues as determined via EOE (in $\mu \mathrm{g}$ oil) or $\mathrm{PO}^{13} \mathrm{C}$ measurements (in $\mu \mathrm{g}$ oil-derived carbon), without taking shifts in specific compound concentrations into account. EOE measures the fluorescent aspects of oil, whereas the $\mathrm{PO}^{13} \mathrm{C}$ calculations were based on the difference in the radio-isotope signature of carbon in the oils from the diatoms. Both measures have inherent biases.

\subsection{Aggregate formation in controls}

Not all diatom species aggregate during bloom termination (Crocker \& Passow 1995, Hansen et al. 1995, Kiørboe et al. 1996), and the triggers causing aggre- gation are still nebulous; it is thus important to monitor aggregation in the controls of each individual experiment. As expected, the aggregation behavior of diatoms in controls differed between species. Whereas substantial aggregation took place within a few days in the controls of Expts 1, 2 and 3, the formation of visible aggregates took $\geq 12 \mathrm{~d}$ in Expts 4 and 5 , and even then only a few unsubstantial aggregates formed (Table 3, Fig. 1). Thus, Expts 4 and 5 ran much longer than Expts 1 to 3.

On average, cell numbers in control treatments decreased by 6 to $29 \%$ over time compared to the respective $t=0$ value in all experiments except in Expt 1, where no significant net change was observed (Table 4). In Expt 3, the overall decrease of $11 \%$ by Day 3 was significant, but a small, initial increase in cell numbers of controls observed on Day 2 (data not shown) suggests that tanks harvested on Days 2 and 3 may not have been good replicates, although the appearance and measured characteristics of aggregates did not differ between the 2 days.

Aggregation rate may be assessed by the appearance of aggregates $>1 \mathrm{~mm}$ (number and size), or from the partitioning of particles between the Agg and the SSW phases. Visual observations indicated that, whereas the aggregation rates were high (i.e. rapid appearance of many aggregates) in the controls of Expts 1, 2 and 3, only very few, unsubstantial aggregates formed in the controls of Expts 4 and 5, even after $\geq 12$ d (Table 3 ). Consistent with this observation, significant fractions of POC, PON and TEP

Table 3. Observations of marine snow formation. $\mathrm{WAF}_{\mathrm{Ref}}$ and $\mathrm{WAF}_{\mathrm{Mac}}$ : water accommodated fraction of Refugio and Macondo oil

\begin{tabular}{|c|c|c|}
\hline Expt & Diatom added & Visual observations and notes on handling \\
\hline 1 & Skeletonema grethae-CCMP 775 & $\begin{array}{l}\text { Large, but very loose, fragile aggregates. For analysis, samples from } \\
\text { replicate tanks were combined. Due to the fragile nature, aggregates } \\
\text { may have been lost during harvest, implying underestimation of the } \\
\text { aggregated fraction }\end{array}$ \\
\hline 2 & S. grethae-CCMP 776 & $\begin{array}{l}\text { 1000s of } 1 \mathrm{~mm} \text { spherical, cohesive aggregates. } \mathrm{WAF}_{\mathrm{Ref}} \text { aggregates } \\
\text { are larger than in control and } \mathrm{WAF}_{\mathrm{Mac}} \text { each consisting of the small } \\
\text { spherical aggregates sticking together. Aggregates in } \mathrm{WAF}_{\text {Ref }} \text { were } \\
\text { especially sticky and hard to handle }\end{array}$ \\
\hline 3 & Odontella auriata CCMP 816 & $\begin{array}{l}10-50 \text { aggregates of all sizes, up to } 3 \mathrm{~cm} \text {. At day of harvest mostly } \\
\text { between } 1-20 \text { aggregates }>4 \mathrm{~mm} \text {. No significant visual differences } \\
\text { between treatments }\end{array}$ \\
\hline 4 & Chaetoceros sp. & $\begin{array}{l}\text { Aggregates took a long time in forming and were very wispy and } \\
\text { unsubstantial, growing larger, but remaining wispy and stringy. } \\
\text { Only a few aggregates in each tank, containing little 'solid' particles }\end{array}$ \\
\hline 5 & Thalassiosira pseudonana CCMP 1335 & $\begin{array}{l}\text { Tiny aggregates started forming Day 12, but most diatoms remained } \\
\text { unaggregated in the water }\end{array}$ \\
\hline
\end{tabular}



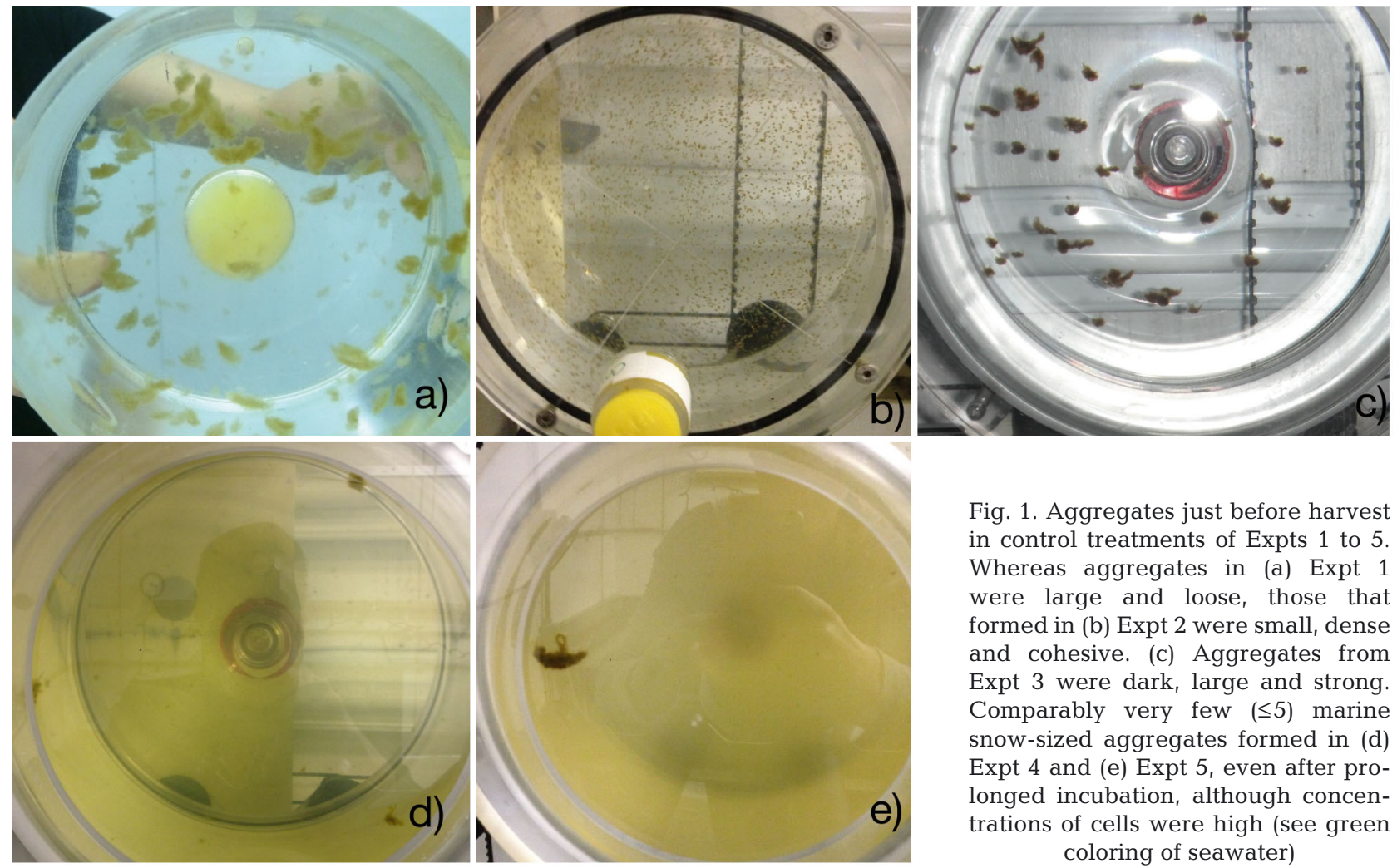

Fig. 1. Aggregates just before harvest in control treatments of Expts 1 to 5 . Whereas aggregates in (a) Expt 1 were large and loose, those that formed in (b) Expt 2 were small, dense and cohesive. (c) Aggregates from Expt 3 were dark, large and strong. Comparably very few $(\leq 5)$ marine snow-sized aggregates formed in (d) Expt 4 and (e) Expt 5, even after prolonged incubation, although concentrations of cells were high (see green coloring of seawater)

$(>70 \%)$ were incorporated into aggregates in the controls of Expts 1, 2 and 3, but less than $20 \%$ of the material aggregated in Expts 4 and 5 (Fig. 2). Partitioning of cells followed the same trend as POC/PON in Expts 2, 4 and 5, and indicated reduced cell aggregation in Expt 3 (Fig. 2). Cell counts were not possible in Expt 1.

Table 4. Changes in cell concentrations during the experiments $(t=0$ to harvest) and total (aggregate phase + surrounding seawater; Agg + SSW) transparent exopolymer particles (TEP) concentration normalized to particulate organic nitrogen (PON) at harvest. Standard deviation between replicates using error progression was less than $\pm 15-20 \%$. $\mathrm{WAF}_{\text {Ref }}$ and $\mathrm{WAF}_{\mathrm{Mac}}$ : water accommodated fraction of Refugio and Macondo oil $\mathrm{GX}_{\mathrm{eq}}$ : gum xanthan equivalent. See Table 1 for the individual species tested in the experiments

\begin{tabular}{|c|c|c|c|c|c|c|}
\hline \multirow[t]{2}{*}{ Expt } & \multicolumn{3}{|c|}{$\begin{array}{l}\text { Average decrease in } \\
\text { cell concentration (\%) }\end{array}$} & \multicolumn{3}{|c|}{$\begin{array}{c}\text { Total TEP normalized } \\
\left.\text { to PON ( } \mu \mathrm{g} \mathrm{GX}_{\mathrm{eq}} \mu \mathrm{g}^{-1} \mathrm{PON}\right)\end{array}$} \\
\hline & Control & $\mathrm{WAF}_{\mathrm{Mac}}$ & $\mathrm{WAF}_{\mathrm{Ref}}$ & Control & $\mathrm{WAF}_{\mathrm{Mac}}$ & $\mathrm{WAF}_{\mathrm{Ref}}$ \\
\hline 1 & $0^{\mathrm{a}}$ & $\geq 2^{\mathrm{a}}$ & - & - & - & - \\
\hline 2 & 27 & 79 & 83 & 5.5 & 2.7 & 2.2 \\
\hline 3 & 11 & 20 & 28 & 4.7 & 5.3 & 5.7 \\
\hline 4 & $29^{a}$ & - & $\geq 36^{\mathrm{a}}$ & 7.6 & - & 3.5 \\
\hline 5 & 6 & 3 & 13 & 7.3 & 9.6 & 10.0 \\
\hline
\end{tabular}

\subsection{Impact of WAF}

A comparison of aggregate formation and composition between WAF treatments and controls allowed us to examine the impact of WAF on aggregation, the temporal development of diatom abundance and TEP production. Comparison between the effects of the 2 WAFs revealed information on the role of oil type. PON rather than POC was used as a proxy for cell biomass, because POC measurements include carbon from oil droplets.

Aggregation rates, based on PON partitioning, were not consistently impacted by the presence of WAF. The fraction of PON partitioned into Aggs was slightly higher (Expt 2), slightly lower (Expts 1, 3,5) or similar (Expt 4) in WAF treatments compared to control treatments (Fig. 2). The fraction of identifiable cells in aggregates that contained oil (WAF treatments) was, however, appreciably reduced compared to controls in all experiments, except in Expt 4 (Fig. 2). For example, whereas $80 \%$ of all 


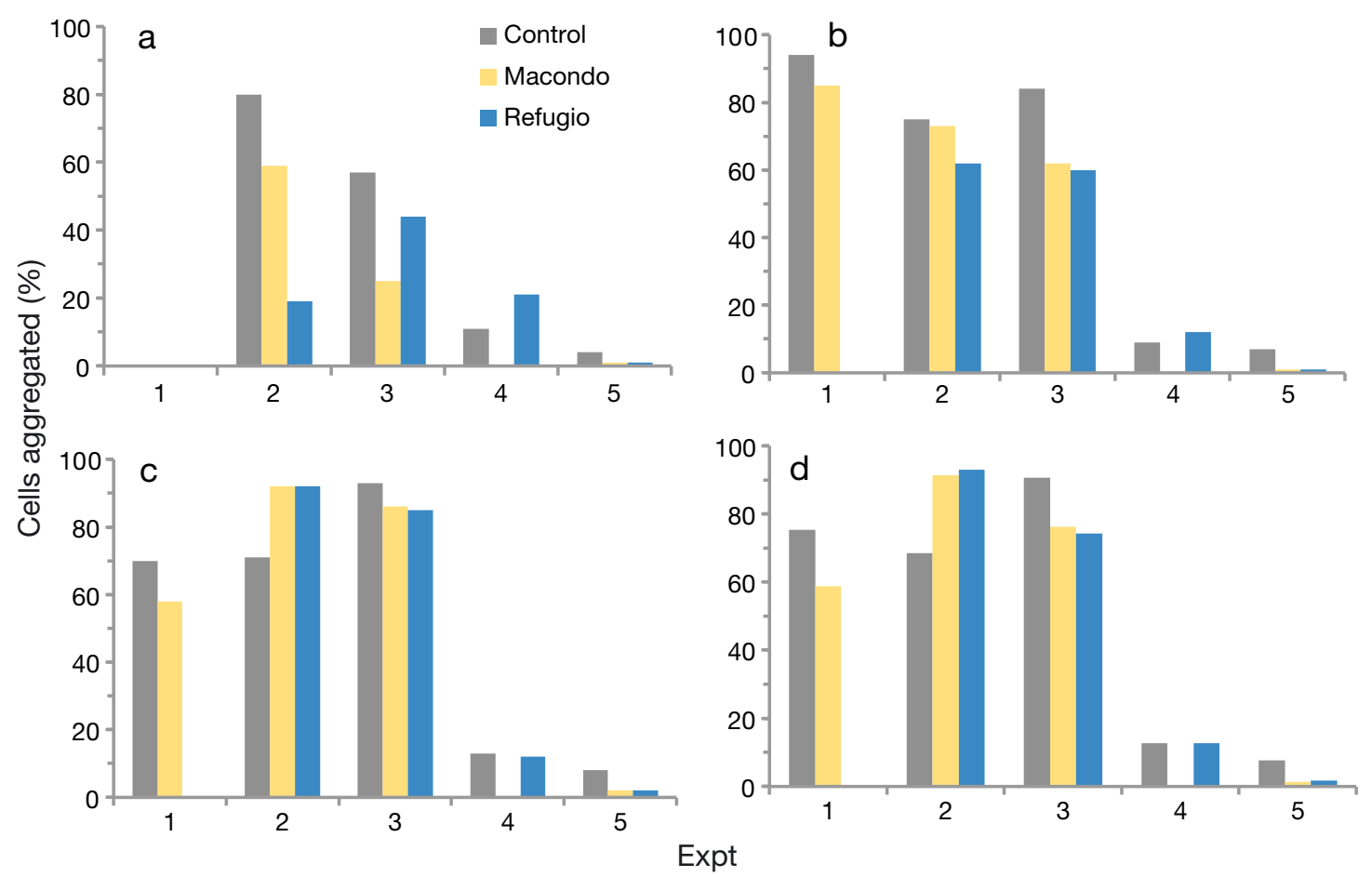

Fig. 2. Percentage of (a) cells, (b) transparent exopolymer particles (TEP), (c) particulate organic carbon (POC) and particulate organic nitrogen (PON) that were aggregated in Expts 1 to 5

diatom cells resided within Aggs in controls of Expt 2, only 59 and $19 \%$ of diatoms were aggregated in the $\mathrm{WAF}_{\mathrm{Mac}}$ and $\mathrm{WAF}_{\text {Ref }}$ treatments, respectively. Closer inspection suggests that diatom cells in aggregates containing oil disintegrated to the point that they were no longer microscopically recognizable as cells. In fact, $98 \%$ of 'cells' counted in Expt 3 were recognizable as independent units, but did not look like typical Odontella aurita cells. Chaetoceros sp., used in Expt 4, appeared to have been less affected by WAF than the other diatoms. So while WAF did not systematically impact aggregation, it did affect individual cells within oil-containing aggregates.

The absence of an impact of WAF on aggregation success, even when aggregation rates in controls were low (Expts 4 and 5), seems to contrast with previous experiments, where oil appeared to promote aggregation when natural aggregation rates were low (Passow et al. 2017). Those experiments simulated the formation of oil-containing aggregates in the presence of an oil slick, where liquid oil, rather than dispersed and dissolved oil (i.e. WAF) was added. Liquid oil promoted aggregation in cases where the aggregation rate was low in the control, but no further effect was visible when aggregation potential was already high in controls. The addition of WAF did not have the same expediting effect on aggregation as did liquid oil.
The decrease in total (Agg + SSW) diatom abundances during all 5 experiments was always larger in WAF treatments compared to controls, and larger in $\mathrm{WAF}_{\text {Ref }}$ compared to $\mathrm{WAF}_{\mathrm{Mac}}$ treatments (Table 4), suggesting that $\mathrm{WAF}$, and especially $\mathrm{WAF}_{\text {Ref, }}$ had a detrimental impact on diatoms. This negative effect on diatom abundance is consistent with the negative impact on cell appearance. Most studies on the influence of WAF on phytoplankton investigate the growth phase rather than the aggregation and sedimentation phase of the diatom life cycle. Responses to the presence of oil in growing phytoplankton, and in diatoms in particular, vary widely from positive to neutral or negative (see discussion in Özhan et al. 2014, Bretherton et al. 2018, Ladd et al. 2018). This appears to be driven by differences in their physiological responses to the oil; the specific mechanisms and processes remain to be elucidated (Bretherton et al. 2018). Our experiments suggest that a negative impact of oil may also be expected when growth of cells has ceased or nearly ceased. Survival or transition to resting stages in diatoms after active growth ceases is not well understood, but clearly the presence of oil compounds affected this phase of the lifecycle in 4 out of 5 diatoms tested. In situ, the DwH spill is thought to have had an overall negative impact on phytoplankton abundance, although not diatoms (Parsons et al. 2015), and individual blooms 
may even have benefited, either directly, from the presence of the oil itself, or indirectly, from reduced grazing due to the presence of oil (Hu et al. 2011).

The impact of WAF on cellular TEP production was inconsistent: total PON-normalized TEP concentrations were higher, lower or similar in controls compared to WAF treatments (Table 4). PON-normalized TEP production was higher in controls compared to WAF treatments in Expt 2 and similar in Expt 3, suggesting that oil does not spontaneously induce increased cellular TEP release in non-growing diatoms. Increased TEP production in the presence of WAF during the growth phase of phytoplankton has been observed in mesocosm experiments (Bretherton et al. 2019). Increased TEP production during the termination phase of a bloom may also be expected when the bloom decline is caused by nutrient limitation in the presence of sufficient light for growth (Passow 2002). In the experiments discussed here, aggregation was induced via light limitation, and all nutrients were non-limiting (data not shown). Apparently, TEP production of actively growing diatoms may be enhanced by WAF, but responses are more complex once growth stops. Bacterial activity, which commonly increases when blooms terminate, makes TEP dynamics even more complex, because bacteria produce, utilize and modify TEP (Passow 2002).

Expts 2, 3 and 5, which allowed a direct comparison between the impacts of $\mathrm{WAF}_{\mathrm{Mac}}$ and $\mathrm{WAF}_{\text {Ref, }}$ suggest that the total decrease in diatom abundance over time was always larger in $\mathrm{WAF}_{\text {Ref }}$ than in $\mathrm{WAF}_{\text {Mac }}$ treatments. This may be due to differences in toxicity between the 2 oils, or may reflect the higher dispersability of the Refugio incident oil, which led to higher oil concentrations. No consistent impact on PON-normalized TEP production was observed (Table 4), and aggregation rates, measured as the fraction of aggregated PON, did not differ between the 2 types of WAF (Fig. 2), implying that the enhanced disintegration of cells in $\mathrm{WAF}_{\text {Ref }}$ did not cause increased aggregation. This may be because cells that were already aggregated, rather than unaggregated ones, appeared to be preferentially negatively affected. The close contact between hydrocarbons and cells in aggregates may have resulted in increased overall exposure of cells to hydrocarbon compounds compared with cells in the SSW. This would explain the observed visible negative impacts on aggregated cells, but not on freely suspended cells.

\subsection{Oil incorporation into aggregates}

Incorporation of oil into aggregates varied widely between experiments and oil types: based on $\mathrm{PO}^{13} \mathrm{C}$ calculations, the contribution of oil-derived carbon to the total amount of aggregated POC ranged from 5 to $42 \%$ (carbon:carbon), with values $<10 \%$ in $\mathrm{WAF}_{\mathrm{Mac}}$ of Expts 1, 2 and 3, around $15 \%$ in $\mathrm{WAF}_{\text {Ref }}$ treatments of Expts 2 and 3, and $\geq 35 \%$ in Expts 4 and 5 (Table 5). In Expts 4 and 5 the calculated oil contribution to aggregates may be overestimated. It is possible that free, unaggregated oil droplets were unintentionally sampled in those experiments, where the stringy aggregates were very difficult to collect and a significant amount of surrounding seawater may have been inadvertently sampled as well. The exceptionally large variability in $\mathrm{PO}^{13} \mathrm{C}$ signature $(-23.1$ and $-30.5 \%$ ) and $\mathrm{C}: \mathrm{N}$ ratios (6.4 and 15.5 ) between replicate 'aggregates' of Expt 5 suggests that in this experiment, some dispersed oil droplets may have been sampled unintentionally together with one of the aggregate samples, thus artificially increasing the amount of oil thought to be associated with the aggregate. We thus assume that the oil-derived carbon contribution to POC of $35 \%$ in aggregates from the $\mathrm{WAF}_{\text {Ref }}$ treatment of Expt 5 is likely an overestimate. However, there was no indication of a similar problem in Expt 4, where $40 \%$ of POC was oilderived carbon.

Table 5. Incorporation of oil into aggregates. Standard deviations for estimated oil equivalence (EOE) are small, but see discussion on assumptions and errors in Section 2.3.1. POC: particulate organic carbon; $\mathrm{WAF}_{\mathrm{Mac}}$ and WAF $\mathrm{Ref}_{\mathrm{R}}$ : water accommodated fraction of Refugio and Macondo oil

\begin{tabular}{|c|c|c|c|c|c|}
\hline \multirow[t]{2}{*}{ Expt } & \multirow[t]{2}{*}{ Diatom } & \multicolumn{2}{|c|}{$\begin{array}{l}\text { Contribution of oil-derived carbon to POC } \\
\text { of aggregates (based on EOE; assumption } \\
\text { of } 85 \% \text { of EOE is oil-derived carbon) }\end{array}$} & \multicolumn{2}{|c|}{$\begin{array}{l}\text { Contribution of oil-derived } \\
\text { carbon to POC of aggregates } \\
\text { (based on } \mathrm{PO}^{13} \mathrm{C} \text { ) }\end{array}$} \\
\hline & & $\mathrm{WAF}_{\mathrm{Mac}}(\%)$ & $\mathrm{WAF}_{\mathrm{Ref}}(\%)$ & $\mathrm{WAF}_{\mathrm{Mac}}(\%)$ & $\mathrm{WAF}_{\mathrm{Ref}}(\%)$ \\
\hline 1 & Skeletonema grethae-775 & & & 5 & - \\
\hline 2 & S. grethae- 776 & 0.7 & 1.4 & & \\
\hline 3 & Odontella auriata & 0.3 & 1.0 & $6 \pm 3 \%$ & $15 \pm 1 \%$ \\
\hline 4 & Chaetoceros sp. & & 3.5 & - & 42 \\
\hline 5 & Thalassiosira pseudonana & 0.3 & 0.6 & - & 35 \\
\hline
\end{tabular}


In general, the range of oil-derived carbon contribution to total POC of diatom aggregates as calculated from $\mathrm{PO}^{13} \mathrm{C}$ fits within the lower range of previously published values where oil was added directly, not as WAF: oil compounds contributed between 7 and $65 \%$ to the POC of diatom aggregates in those earlier experiments conducted with a visible oil slick at the water surface (Passow 2016, Passow et al. 2017). This implies a higher oil incorporation rate when oil is added directly, as liquid oil, into the rolling tank, rather than as dispersed and dissolved oil (i.e. WAF).

Oil incorporation into aggregates as estimated from EOE measurements also varied widely, ranging from $0.7 \mu \mathrm{g}$ EOE (Expt 5) to $109 \mu \mathrm{g}$ EOE (Expt 2) associated with the aggregate phase per hypothetical $1 \mathrm{l}$ tank (or 4 to $559 \mu \mathrm{g}$ EOE $\operatorname{tank}^{-1}$ ). When normalized to aggregated PON, the amount of oil associated with aggregates varied less, ranging from 37 to $48 \mathrm{ng}$ EOE $\mu^{-1}$ PON in $\mathrm{WAF}_{\mathrm{Mac}}$ treatments and from 74 to $179 \mathrm{ng} \mathrm{EOE} \mathrm{gg}^{-1} \mathrm{PON}$ in $\mathrm{WAF}_{\text {Ref }}$ treatments (Fig. 3). Based on these values, and assuming an oilderived carbon content of $85 \%$ of EOE, an oil contribution between 0.3 and $3.5 \%$ to the POC of aggregates can be estimated ( $\mu \mathrm{g}$ oil-derived carbon $\mu \mathrm{g}^{-1}$ POC). This is significantly lower than the estimates based on $\mathrm{PO}^{13} \mathrm{C}$ measurements.

The amount of oil incorporated into aggregates, as estimated from $\mathrm{PO}^{13} \mathrm{C}$-based calculations and from EOE measurements, correlated well, but differed by almost an order of magnitude (reduced major axis, $\mathrm{EOE}=0.11 \pm 0.02 \times$ oil-derived carbon $-32.5 \pm 16.7$; $\mathrm{r}=0.95, \mathrm{n}=6$; with EOE in $\mu \mathrm{g}$ oil and oil-derived carbon in $\mu \mathrm{g}$ ). This discrepancy may be explained by the erroneous assumption that the cells forming aggre-

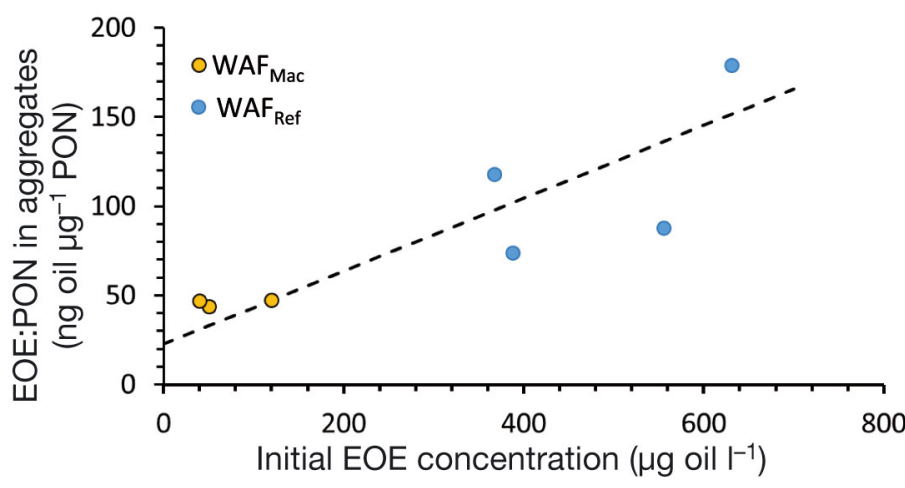

Fig. 3. Aggregated oil measured as estimated oil equivalent (EOE) normalized to aggregated particulate organic nitrogen (PON) as a function of initial oil concentration (as EOE). Correlation line calculated as reduced major axis: $y=0.20$ $( \pm 0.05) x+22.69( \pm 19.58), \mathrm{R}=0.84$. Pearson regression: $y=$ $0.17 x+32.54, \mathrm{R}=0.84$. WAF: water accommodated fraction of oil; Mac: Macondo oil; Ref: Refugio oil gates in the WAF treatments were physiologically similar to those in the controls. On the one hand, the aforementioned continued growth of cells in aggregates of control treatments impacted their $\mathrm{PO}^{13} \mathrm{C}$ signatures, but the assumption that a similar process was occurring in aggregates of WAF treatments appears unjustified. Visually, cells in aggregates of WAF treatments looked senescent, rather than growing. The assumption of a similar physiology of cells in the 2 treatments led to an overestimation of oil incorporation based on $\mathrm{PO}^{13} \mathrm{C}$ calculations. On the other hand, the corrections for the interference of chl $a$ in EOE measurements assume that the chl a content was the same in the control and WAF treatments, which would lead to an underestimate of the oil content based on EOE determinations, if the assumption that cells were compromised in aggregates of WAF treatments is true. Thus, the discovery that cells in aggregates of WAF treatments were negatively affected compared to those in controls, i.e. that they have a lower chl a content and did not initially grow, would result in a systematic overestimation of oil incorporation rates based on $\mathrm{PO}^{13} \mathrm{C}$ calculations and a simultaneous underestimation of those based on EOE measurements. This explains the good correlation between the 2 estimates and suggests that correct values lie somewhere in between, ranging from a few to $20 \%$ oil-derived carbon per aggregate in these experiments.

Visual estimates of the relative volume fractions of oil droplets within aggregates suggest that oil may comprise between $1 / 4$ and $1 / 3$ of the volume fraction of an aggregate when oil is added directly rather than as WAF. Since the carbon content of a given volume of oil is high compared to that of an equivalent volume of modern organic matter, and since oil compounds in diatom aggregates exist as oil droplets as well as being sorbed to cell surfaces (Wirth et al. 2018), the total contribution of oil-derived carbon to total POC may be higher than suggested by volume fraction.

This discussion reveals that establishing the maximum carrying capacity of a diatom aggregate for oil is difficult. The different estimates from experiments described here suggest that likely less than about $40 \%$ of the carbon content of an aggregate may be oil compounds. Earlier work conducted with liquid oil rather than WAF suggests a slightly higher oil carrying capacity, possibly above $50 \%$ of oil-derived carbon (Passow 2016, Passow et al. 2017). There are likely species- and aggregate-specific differences as well. Our best estimate for the carrying capacity of diatom aggregates for oil is somewhere around 40 to 
$50 \%$. This maximum carrying capacity of oil will likely rarely be observed in situ. In rolling tanks, the oil and the aggregates are contained for hours within a small volume, without dispersion and dilution effects, resulting in the continued uptake of oil. In situ encounter rates between oil droplets and diatoms will likely be lower, as aggregates sink through the oil-containing layer. Our experiments also suggest that oil incorporation into aggregates is lower when WAF rather than liquid oil is added to the rolling tank, presumably because larger oil droplets than those existing in WAF are incorporated into aggregates when oil is added directly (U. Passow pers. obs.). This means that a bloom that aggregates near the sea surface in the presence of an oil slick would likely incorporate more oil into aggregates than one that aggregates subsurface, below an oil slick.

We hypothesized that oil content in aggregates would be a function of the initial oil concentration in the surrounding seawater. This was indeed the case, but only when aggregate oil content was normalized by total aggregated biomass (Fig. 3). Neither initial oil concentration, nor aggregated biomass alone, could satisfactorily explain oil incorporation. This is consistent with coagulation theory (Jackson 1990, Burd \& Jackson 2009) and the fact that oil droplets cannot form aggregates (which are fractal) with themselves, but instead would form large drops. Some minimum concentration of particles is needed per oil droplet to allow oil-particle aggregates to form.

In previous experiments on oil incorporation into aggregates (Passow et al. 2017), initial oil concentrations were estimated to range between 0.15 and $4.60 \mathrm{mg}$ oil-derived carbon $\mathrm{l}^{-1}$. An estimate of EOE based on the relationship established here suggests that these points fall onto the curve shown in Fig. 3, with one exception: at the very high initial oil concentration of $4.6 \mathrm{mg}$ oil-derived carbon $\mathrm{l}^{-1}$, achieved via chemical dispersion with Corexit, the oil-derived carbon contribution to total aggregated POC was $64 \%$, only slightly higher than that of an initial oil concentration an order of magnitude lower $(0.40 \mathrm{mg}$ oil-derived carbon $\mathrm{l}^{-1}$ ), where $\sim 59 \%$ of aggregated carbon was due to oil. This confirms that an oilderived carbon contribution of roughly $50 \%$ may be the maximum carrying capacity of diatom aggregates, and is consistent with our derived relationship between oil content per aggregate and initial oil concentration in the water. Data from the experiments presented here thus confirm and extend results from earlier experiments which investigated the effect of an oil slick on oil incorporation into diatom aggregates.

\subsection{The role of exudates for aggregation: TEP and EDTA-extractable EPS}

Aggregate formation in diatoms can be predicted from their collision frequency, a function of cell concentration, and stickiness, which is defined as the probability that cells remain attached after collision (Jackson 1990, 2005, Burd \& Jackson 2009). The nonspherical shapes and varying cell sizes of diatoms in a population make a direct comparison of collision frequencies difficult, but cell concentrations in all 5 of our experiments were high compared to natural concentrations, and collision frequencies must have been high enough to allow rapid aggregation in all 5 experiments. The greatly reduced aggregation success in Expts 4 and 5 compared to Expts 1 to 3 is thus likely due - at least in part - to reduced stickiness.

TEP, which are a subgroup of EPS, have been postulated to appreciably increase aggregation success of phytoplankton (Jackson 1995, Logan et al. 1995, Arrigo 2007), in large part because of their high stickiness (Mari et al. 2017). TEP are operationally defined as particles rich in acidic polysaccharides (Passow \& Alldredge 1995), like uronic acids and sulfur half-ester groups (Mopper et al. 1995, Zhou et al. 1998). However, whereas TEP concentrations are a good predictor of aggregation within a given system (Gärdes et al. 2011), a generally applicable relationship between TEP abundance and aggregation success has not been observed (Mari et al. 2017), likely because of the chemical heterogeneity of substances identified as TEP.

The composition of EDTA-extractable EPS, another sub-group of EPS, and specifically its protein-tocarbohydrate ratio $(\mathrm{P} / \mathrm{C})$ is also hypothesized to act as a proxy for stickiness and aggregation potential, because P/C is an indicator of relative hydrophobicity of EPS (Xu et al. 2011, Zhang et al. 2012, Quigg et al. 2016). A high protein-to-carbohydrate ratio in EPS could promote aggregation of cells via rapid hydrophobic interactions (Xu et al. 2011). Combining these 2 hypotheses, we examined TEP abundance and the composition of the EDTA-extractable EPS as a means to predict aggregation success. In the following, we first explore the relationship between TEP and particulate EDTA-extractable EPS, which is largely unknown, and discuss if TEP concentration and the composition of EDTA-extractable EPS can predict the propensity of cells to aggregate.

In terms of carbon, TEP concentrations were more than an order of magnitude higher than the EDTAextractable EPS concentrations. For example, aggregates in Expts 1, 2 and 5 contained between 600 and 
$55000 \mu \mathrm{g}$ TEP-carbon per tank, compared to 40 to $2600 \mu \mathrm{g}$ EDTA-extractable EPS-carbon per tank. Whereas TEP-carbon contributed on average nearly $40 \%$ to the aggregated carbon, the EDTA-extractable EPS contributed $3.9 \pm 1.2 \%$ to POC in aggregates. Although EDTA-extractable EPS constituted a much smaller fraction of EPS than TEP, TEP and EDTAextractable EPS were significantly correlated (reduced major axis, $\mathrm{r}=0.77, \mathrm{n}=14, \mathrm{p}<0.0005$; Fig. 4).

About half of the EDTA-extractable EPS $(42 \pm 12 \%)$ could be characterized as either neutral carbohydrates, uronic acids or proteins (Table 6), and a highly significant correlation was found between TEP and the uronic acid content of the EDTAextractable EPS $(\mathrm{r}=0.89, \mathrm{n}=14, \mathrm{p}<0.0005$; Fig. 4), although there is a fair amount of scatter both at low and high TEP-carbon concentrations. TEP was not correlated to neutral sugar content of the EDTA-extractable EPS, confirming that TEP is indeed enriched in acidic polysaccharides, but not neutral carbohydrates. A tight correlation was, however, observed between TEP and proteins of the EDTA-extractable EPS $(\mathrm{r}=0.94, \mathrm{n}=14, \mathrm{p}<$ 0.0005), emphasizing the importance of proteins in TEP (Fig. 4). TEP, although operationally defined by their acidic polysaccharides, also include other substance classes (Verdugo \& Santschi 2010, Quigg et al. 2016, Winters et al. 2016).

High aggregation rates in Expts 1,2 and 3 compared to Expts 4 and 5 were not simply attributable to differences in absolute, or cell-normalized, TEP concentrations; total TEP concentrations differed widely between experiments, with concentrations in control treatments ranging from $4.1 \mathrm{mg} \mathrm{GX}_{\text {eq }} \mathrm{l}^{-1}$ in Expt 2, to $64.6 \mathrm{mg} \mathrm{GX}_{\text {eq }} \mathrm{l}^{-1}$ in Expt 3, and intermediate values around $10 \mathrm{GX}_{\mathrm{eq}} \mathrm{l}^{-1}$ in Expts 1, 4 and 5. These differences in total TEP concentration appear to be diatom-specific. PON-normalized TEP content varied between 3 and $10 \mu \mathrm{g} \mathrm{GX}_{\text {eq }} \mu \mathrm{g}^{-1} \mathrm{~N}$ (Table 4). PON-normalized TEP content in the controls was higher in Expts 4 and 5 where aggregation success was lower

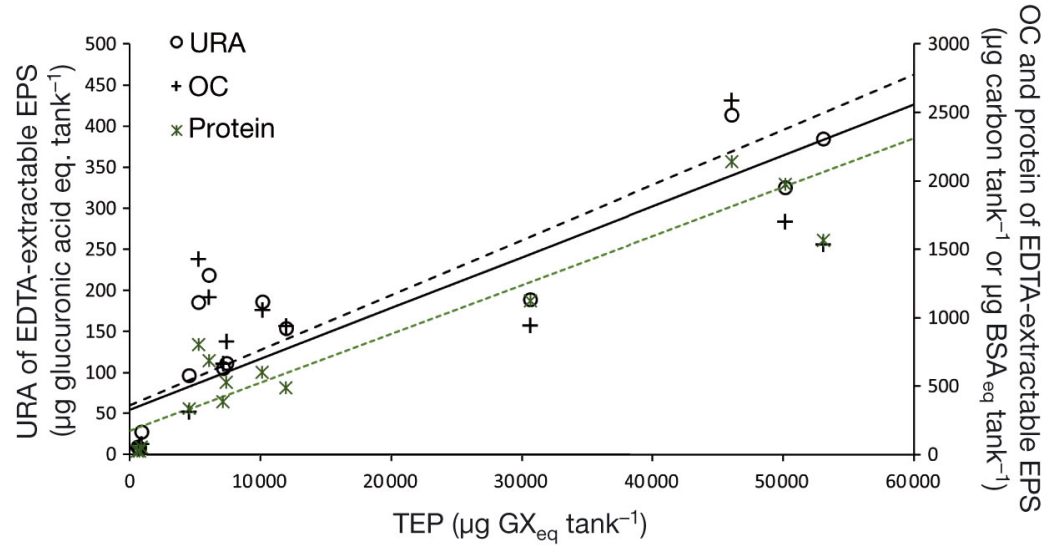

Fig. 4. Uronic acid (URA), organic carbon (OC) or protein content of EDTA-extractable exopolymeric substances (EPS) correlated with transparent exopolymer particles (TEP). URA: left axis, $y=0.0067 x+60.5764$, $\mathrm{R}=0.89$; OC: right axis, $y=0.0372 x+328.0 .4, \mathrm{R}=0.77$; protein: right axis, $y=0.0357 x+169.5962, R=0.94$. All correlations calculated as major reduced axis. $\mathrm{BSA}_{\text {eq: }}$ bovine serum albumin equivalent

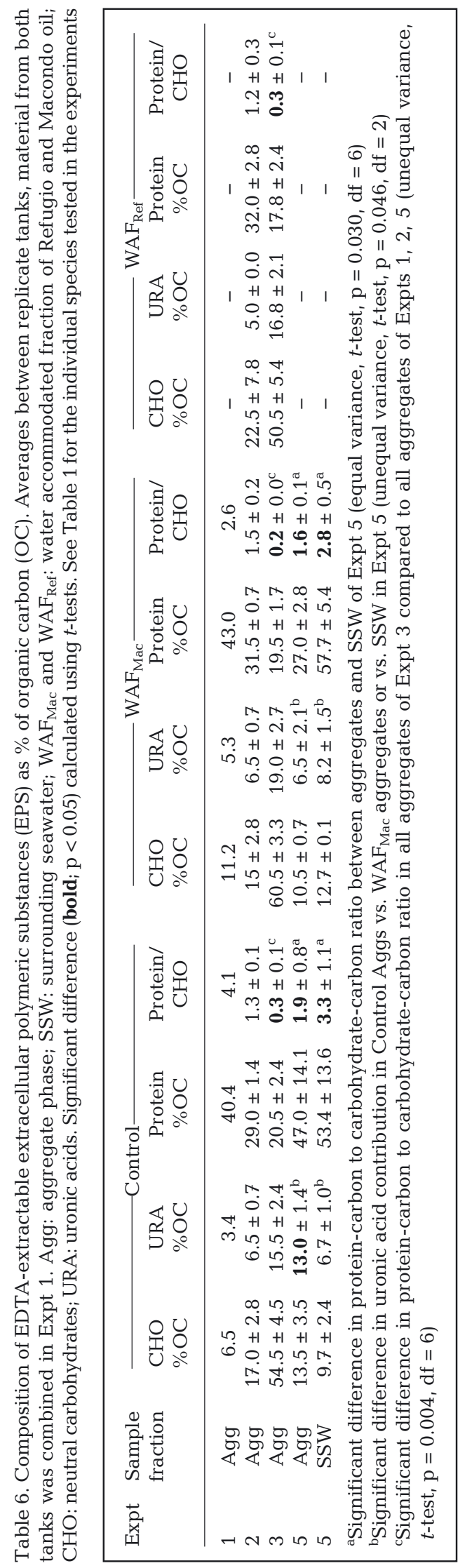


compared to Expts 1 to 3 (Table 4). Other factors than TEP abundance, presumably stickiness of TEP and of the cells themselves, must have played a central role in determining aggregation success in these 5 experiments.

The composition of EDTA-extractable EPS harvested from the particulate phase of aggregates varied widely between experiments (Table 6). EDTAextractable EPS of Expt 3 was characterized by the very high contribution of neutral sugars $(\geq 50 \%)$ compared to Expts 1, 2 and $5(<25 \%)$. Uronic acids contributed a small fraction, between 5 and $20 \%$, to EDTA-extractable EPS, with the highest uronic acid to neutral carbohydrate ratio in Expt 5 (Table 6). In accordance with the results from culture experiments (Xu et al. 2011, Zhang et al. 2012) the P/C ratio of the particulate EDTA-extractable EPS was $>1$, except in Expt 3, where it ranged between 0.2 and 0.3 (carbon per carbon). However, our experiments do not suggest that the low protein content of EDTAextractable EPS in Expt 3 translated to low aggregation success. Possibly a lower stickiness, as measured by the P/C ratio of EDTA-extractable EPS, was compensated for by high concentrations, as measured by TEP. Higher collision frequency could compensate for overall lower stickiness. But our data set is too small to show if a general relationship like that exists. In contrast to the findings in a mesocosm experiment (Xu et al. 2018), the P/C ratio was higher in the SSW fraction than in the Agg fraction (Table 5, Expt 5) in both WAF and control treatments, also suggesting no generally consistent effect of oil on this ratio. The heterogeneity in the composition of EDTA-extracted EPS between experiments or species indicates that high relative protein content cannot easily be inter-

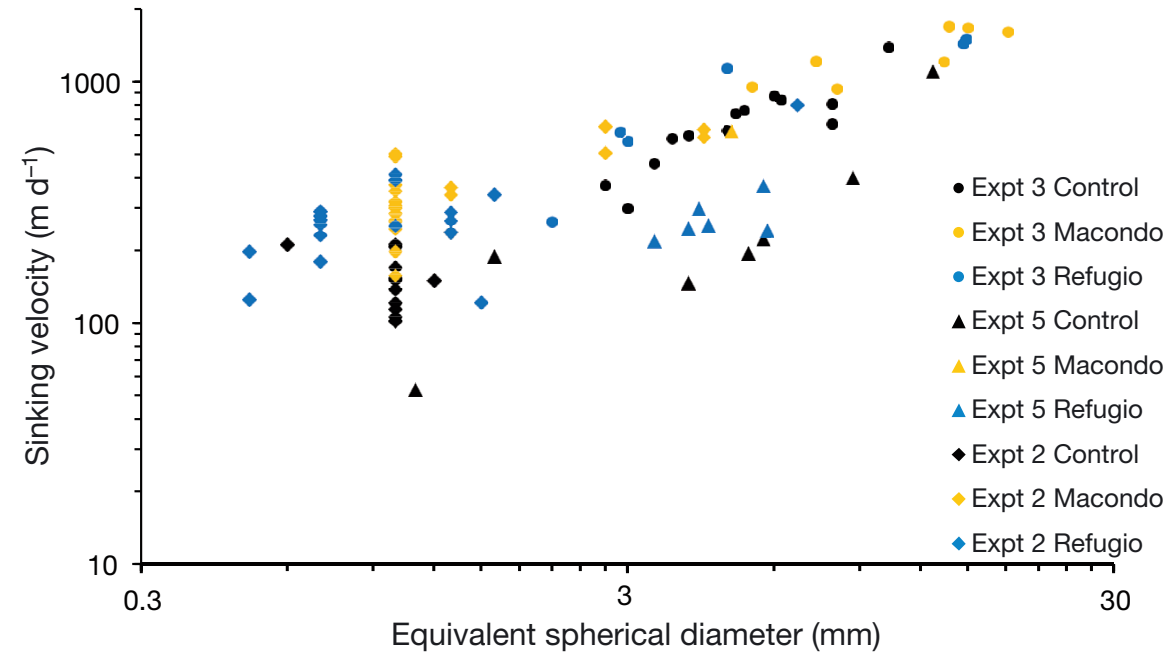

Fig. 5. Sinking velocity of aggregates as a function of aggregate size preted as an exudation response to oil, or translated to high aggregation success. The reactivity of different proteins may vary too widely and is too complex. Additionally, charged polymers, e.g. anionic EPS, facilitate aggregation via $\mathrm{Ca}^{2+}$ bridging (Alldredge et al. 1993), also effectively obscuring a simple direct relationship between the $\mathrm{P} / \mathrm{C}$ ratio of EDTAextractable EPS and stickiness. Overall, in our experiments TEP concentration and the composition of EDTA-extractable EPS could not explain the high aggregation rates in Expts 1, 2 and 3 compared to the low aggregation success in Expts 4 and 5. A suite of different processes likely plays an appreciable role in determining stickiness, depending on the chemical composition of TEP and EPS and other environmental factors.

\subsection{Sinking velocities of aggregates}

Sinking velocities of aggregates from Expts 2, 3 and 5 varied by an order of magnitude, from $\sim 150$ to $1500 \mathrm{~m} \mathrm{~d}^{-1}$, as a function of size (equivalent spherical diameter, ESD; sinking velocity $v=211 \times \mathrm{ESD}^{0.69}, \mathrm{n}=$ 100; Fig. 5). These sinking velocities are on the high end of comparable measurements of laboratory-made diatom snow $\left(v=56 \times \mathrm{ESD}^{0.72}\right.$; Iversen \& Ploug 2010) and within the range of sinking velocities measured on marine oil snow (Passow et al. 2012). Species-specific differences in size and sinking velocity are visible, with average ESD ranging between 1 and $12 \mathrm{~mm}$ (Table 7): $O$. aurita aggregates were the largest and sank most rapidly, on average $\left(980 \mathrm{~m} \mathrm{~d}^{-1}\right)$, whereas Skeletonema grethae-776 aggregates were smallest $(\mathrm{ESD}=1-2 \mathrm{~mm})$ and sank the slowest $\left(267 \mathrm{~m} \mathrm{~d}^{-1}\right)$. Average sinking velocities of aggregates from oil treatments were always higher than in controls, except in the $\mathrm{WAF}_{\text {Ref }}$ treatment for Thalassiosira pseudonana (Expt 5). In Expt 5, the relatively low sinking velocities of aggregates in WAF treatments may have been caused by the high TEP concentrations compared to controls (Table 4); elevated TEP contribution reduces sinking velocities of aggregates (Engel \& Schartau 1999, Azetsu-Scott \& Passow 2004).

The fact that the presence of hydrocarbons tended to increase, rather than decrease, the sinking velocity of aggregates seems counterintuitive, because the density of oil is less than that 
Table 7. Average $( \pm \mathrm{SD})$ size and sinking velocities of aggregates. ESD: equivalent spherical diameter. $\mathrm{WAF}_{\mathrm{Mac}}$ and $\mathrm{WAF}_{\mathrm{Ref}}$ : water accommodated fraction of Refugio and Macondo oil. Sample size (n) for sinking velocities is the same as for ESD. See Table 1 for the individual species tested in the experiments

\begin{tabular}{|c|c|c|c|c|c|c|}
\hline \multirow[t]{2}{*}{ Expt } & \multicolumn{3}{|c|}{ ESD of aggregates $(\mathrm{mm})$} & \multicolumn{3}{|c|}{ - Sinking velocity $\left(\mathrm{m} \mathrm{d}^{-1}\right)$} \\
\hline & Control & $\mathrm{WAF}_{\mathrm{Mac}}$ & $\mathrm{WAF}_{\text {Ref }}$ & Control & $\mathrm{WAF}_{\mathrm{Mac}}$ & $\mathrm{WAF}_{\text {Ref }}$ \\
\hline 2 & $1.0 \pm 0.1, \mathrm{n}=20$ & $1.9 \pm 1.6 ; \mathrm{n}=22$ & $1.3 \pm 1.4 ; \mathrm{n}=18$ & $148 \pm 38$ & $363 \pm 140$ & $290 \pm 149$ \\
\hline 3 & $5.4 \pm 2.2, \mathrm{n}=13$ & $11.6 \pm 4.7 ; \mathrm{n}=7$ & $7.1 \pm 6.1 ; n=6$ & $693 \pm 274$ & $1328 \pm 330$ & $920 \pm 509$ \\
\hline 5 & $5.6 \pm 4.1, \mathrm{n}=7$ & $4.9, \mathrm{n}=1$ & $4.6 \pm 1.0 ; \mathrm{n}=6$ & $330 \pm 356$ & 624 & $272 \pm 55$ \\
\hline
\end{tabular}

of seawater and because aggregates contained significant amounts of oil droplets. According to Stokes' law, which describes the sinking velocity of spherical particles in fluids, sinking velocity is a function of the particle's radius squared and its excess density. The excess density is the density difference between the aggregate and the seawater and is a function of the relative amounts and densities of the different components of the particles (e.g. diatoms, oil) and the porosity of the aggregate (the volume fraction of water). Stokes' law, which assumes non-porous, spherical particles, overestimates the settling velocities of aggregates. Improved estimates of their terminal velocities can be made using White's approximation (White 1991).

Higher sedimentation rates of oil-contaminated aggregates, observed in mesocosms, were attributed to higher ballasting with lithogenic particles, which, it was hypothesized, was due to higher exudate production in the presence of WAF (Xu et al. 2018). No sediment or mineral particles that could have ballasted oil-containing aggregates selectively were present in our experiments, and exudate concentration was not increased in the presence of WAF, except possibly in Expt 5, where sinking velocities of oil-laden aggregates were decreased.

To explore if a change in packaging, i.e. porosity, due to oil may explain the higher sinking velocities of oil-containing aggregates, we calculated the sinking velocity of a hypothetical aggregate of constant size
(5 mm diameter) as a function of porosity (Table 8). The porosity of marine snow-sized diatom aggregates is very high, around 0.985 to 0.998 (Alldredge \& Gotschalk 1988), meaning a diatom aggregate consists mostly of water. Assuming the presence of oil decreases the porosity of an aggregate slightly, allowing for tighter packaging, the number of diatoms included in an oil-containing aggregate of the same size may be larger compared to an aggregate without oil. This is a plausible assumption because capillary bridging between diatoms by oil droplets may result in tighter-packed aggregates in the presence of oil (Strauch \& Herminghaus 2012). In such a case the oil-containing aggregate may have a higher excess density and thus a higher sinking velocity than an equally sized aggregate without oil, although it contains the buoyant oil. Calculations based on reasonable estimates of oil volume (this work), diatom density (e.g. $1.257 \mathrm{~g} \mathrm{~cm}^{-3}$; AzetsuScott \& Passow 2004), seawater density $\left(1.026 \mathrm{~g} \mathrm{~cm}^{-3}\right.$ at $35 \mathrm{ppt}, 15^{\circ} \mathrm{C}$ ) and assuming a slightly decreased porosity in the presence of WAF, suggest that tighter packaging with diatoms in the presence of oil could indeed explain our observations of slightly faster sinking velocities of aggregates containing oil (Table 8). In fact, the sinking velocity of a hypothetical aggregate that contains $6 \%$ oil (based on volume) would sink almost $30 \%$ faster than the control if porosity decreased by 0.02 units. If porosity remained the same, sinking velocity would decrease by $10 \%$.

Table 8. Relative change in the sinking velocity of a hypothetical aggregate of an equivalent spherical diameter (ESD) of $5 \mathrm{~mm}$ due to incorporation of oil. If porosity (packaging) stays constant, sinking velocity will decrease due to the addition of oil to an aggregate (2nd row compared to 1st row), whereas a slightly reduced porosity will result in faster settling velocities of oil-laden aggregates (3rd row compared to 1st row). Assumptions: density of diatoms: $1257 \mathrm{~g} \mathrm{~cm}^{-3}$, oil: $0.865 \mathrm{~g} \mathrm{ml}^{-1}$, seawater: $1.026 \mathrm{~g} \mathrm{~cm}^{-3}\left(15^{\circ} \mathrm{C}, 35 \mathrm{ppt}\right.$ salinity)

\begin{tabular}{|lcccc|}
\hline $\begin{array}{l}\text { Contribution of oil to } \\
\text { solid volume of } \\
\text { aggregate (\%) }\end{array}$ & $\begin{array}{c}\text { Porosity (\%) } \\
\text { assumed }\end{array}$ & $\begin{array}{c}\text { Excess density } \\
\left(\mathrm{g} \mathrm{cm}^{-3}\right) \\
\text { calculated }\end{array}$ & $\begin{array}{c}\text { Reynolds } \\
\text { number } \\
\text { calculated }\end{array}$ & $\begin{array}{c}\text { Sinking velocity (m d }{ }^{-1} \text { ) } \\
\text { (calculated using } \\
\text { White approx.) }\end{array}$ \\
\hline 0 (Control) & 0.990 & 0.0023 & 138 & 796 \\
6 & 0.990 & 0.0021 & 124 & 740 \\
6 & 0.988 & 0.0025 & 149 & 837 \\
\hline
\end{tabular}


Alternatively, the density of diatoms may differ between treatments. Healthy diatoms can regulate their density to remain in the lighted surface ocean. If the physiological state of diatoms degenerates in the presence of oil, an increase in their density may explain increased excess density in oil-containing aggregates. Our observations suggest that the presence of oil in aggregates did result in a change in the physiological state of cells.

\section{CONCLUSIONS}

The overall goal of this study was to provide input parameters for aggregation models that predict the formation of diatom-oil aggregates and the resulting transport of oil to the seafloor. Specifically, the experiments had 3 objectives: first, to determine the oil content of diatom aggregates, so that the sedimentation of oil can be predicted quantitatively as a function of diatom aggregation; second, to identify a proxy for stickiness, so that aggregation success may be modeled realistically; and third, to assess sinking velocity of oil-carrying aggregates, because the transit time of an aggregate to the seafloor determines the degree of degradation and loss. By using 5 different diatom species and 2 types of oil, some understanding of the intrinsic variability of these in situ processes is gained, while clear trends beyond the natural variability may be uncovered.

Our results suggest that initial oil concentration in the water predicted about $70 \%$ of PON-normalized oil content of aggregates. This implies that when oil and phytoplankton concentrations are both known, the amount of oil captured by sinking aggregates may be estimated. Other parameters, such as species composition, also matter, as packaging of cells within aggregates depends on taxa, but a coagulation model would allow a reasonable estimate of oil incorporation into diatom aggregates to be made using cell and oil concentrations as input parameters.

Different estimates of oil incorporation into aggregates suggest that the potential carrying capacity of a diatom aggregate for oil is near $50 \%$ of its total POC. Such high values may likely represent cases when diatom aggregates form at the surface, near an oil slick, but presumably are rare in situ, where oil droplets may disperse and aggregates sink out of an oil-contaminated water layer, reducing the time for interaction. A coagulation model, simulating diatom aggregation, oil incorporation and sedimentation when oil concentrations were relatively low (after DwH), found that oil-derived carbon comprised about $5 \%$ of
POC, with the assumption that $100 \%$ of the oil initially in the water was scavenged (S. Francis \& U. Passow unpubl. data). Assuming high oil concentrations in the water (maximum case scenario), the oil-derived carbon contribution reached close to $50 \%$ of POC. These data indicate that under natural conditions it would be rare, but possible, for diatom aggregates to reach their carrying capacity for oil.

Moreover, we found that TEP and EDTAextractable EPS correlated tightly, although concentrations differed by an order of magnitude. However, in contrast to our second hypothesis, aggregation success in the presence or absence of oil was not readily predictable from TEP concentrations or the protein-to-carbohydrate ratio of EDTA-extractable EPS. The chemical composition of EPS, including that of TEP and EDTA-extractable EPS, and thus the type of possible interactions between these substances and oil, vary widely, obscuring any direct relationship. Additionally, it appears that at least in some cases the presence of oil alters the overall average stickiness of particles, potentially reducing the role of EPS for the formation of oil-containing diatom aggregates. Clearly, more research on the influence of EPS on the interactions between marine biogenic particles and oil residues is needed.

Lastly, we discovered that the sinking velocity of oil-containing aggregates was not decreased compared to equally sized marine snow without oil. On the contrary, sinking velocity seemed slightly increased. Potentially, the oil droplets may allow for tighter packaging of cells, decreasing porosity and resulting in faster sinking. Differences in the packaging of aggregates would have consequences for their fractal dimensions and their behavior, which are currently poorly understood, but a central part of coagulation models (Dissanayake et al. 2018a).

Differences between diatom species or the addition of a natural bacterial inoculum (Expts 4 and 5) had no significant overall effect on these investigated processes, although they likely contributed to the overall variability. However, it appears that simple estimates regarding oil incorporation into aggregates, and the sinking velocities of these aggregates under natural conditions, may be made without taking the dominating species of diatoms or the presence of bacteria into account. EPS production by bacteria as a response to oil may lead to the formation of small (50 $\mathrm{mm}$ ) bacteria-oil aggregations (Baelum et al. 2012, Doyle et al. 2018), which may impact biodegradation of oil but appear to have little consequence in terms of the large sedimentation events (Marine Oil Snow Sedimentation and Flocculent 
Accumulation, MOSSFA) that require marine snowsized aggregates.

An additional essential parameter for aggregation models is the loss rates of sinking aggregates during transit. The discovery that cells in oil-containing aggregates appeared more degraded than the unaggregated cells in the surrounding seawater implies that degradation rates may be higher within oilcontaining aggregates because of their higher exposure to oil compared to non-aggregated cells. Besides microbial degradation, sinking aggregates may be lost due to grazing, or due to fragmentation, e.g. by zooplankton (Dilling et al. 1998, Dilling \& Alldredge 2000, Dilling \& Brzezinski 2004) or turbulence. Loss rates due to disaggregation and the role of oil for these processes are largely unknown. The presence of oil may potentially make aggregates more cohesive, possibly reducing loss due to disaggregation. Ingestion of oil-carrying aggregates by zooplankton will introduce the oil compounds into the pelagic food web rather than carrying them to the seafloor. Future experiments need to focus on degradation of oil and detritus, as well as on the fragmentation and grazing of oil-containing aggregates.

Acknowledgements. We thank Chris Brown, Alicia Williams, Cameron Jackson and Jenifer Genzer for their help during Expt 3. We also thank Lisa DePinto, Chris Reddy, Dave Valentine and others for their help in getting information on the characteristics of the Refugio Incident oil. This research was supported by a grant from The Gulf of Mexico Research Initiative (GoMRI) to support the consortia ADDOMEx and ADDOMEx-2 (Aggregation and Degradation of Dispersants and Oil by Microbial Exopolymers), as well as the project 'Oil-Marine snow mineral interactions'. U.P. was additionally funded by the Multi Partner Oil Research, Canada. The original data can be found at the Gulf of Mexico Research Initiative Information and Data Cooperative (GRIIDC) under dois: 10.7266/N78W3B P3; 10.7266/N70K26Z2; 10.7266/N77D2SHQ; 10.7266/N73 N21SC; 10.7266/N7ZW1JBJ; 10.7266/N780517B.

\section{LITERATURE CITED}

Adcroft A, Hallberg R, Dunne JP, Samuels BL, Galt JA, Barker CH, Payton D (2010) Simulations of underwater plumes of dissolved oil in the Gulf of Mexico. Geophys Res Lett 37:L18605

Alldredge AL, Gotschalk C (1988) In situ settling behavior of marine snow. Limnol Oceanogr 33:339-351

Alldredge AL, Passow U, Logan BE (1993) The abundance and significance of a class of large, transparent organic particles in the ocean. Deep Sea Res I 40:1131-1140

Arrigo KR (2007) Carbon cycle: marine manipulations. Nature 450:491-492

Azetsu-Scott K, Passow U (2004) Ascending marine particles: significance of transparent exopolymer particles (TEP) in the upper ocean. Limnol Oceanogr 49:741-748
Baelum J, Borglin S, Chakraborty R, Fortney J and others (2012) Deep-sea bacteria enriched by oil and dispersant from the Deepwater Horizon spill. Environ Microbiol 14: 2405-2416

*Baguley J, Montagna P, Cooksey C, Hyland J and others (2015) Community response of deep-sea soft-sediment metazoan meiofauna to the Deepwater Horizon blowout and oil spill. Mar Ecol Prog Ser 528:127-140

Beegle-Krause CJ (2001) General NOAA oil modeling environment (GNOME): a new spill trajectory model. IOSC Proc 2001:865-871

Bera G, Gold-Bouchot G, Passow U, Wade TL and others (2019) Inter-laboratory calibration of estimated oil equivalent (EOE) concentrations of a water accommodated fraction (WAF) of oil and a chemically enhanced WAF (CEWAF). Heliyon 5:e01174

Bretherton L, Williams AK, Genzer J, Hillhouse J, Kamalanathan M, Finkel ZV, Quigg A (2018) Physiological response of 10 phytoplankton species exposed to Macondo oil and the dispersant, Corexit. J Phycol 54: 317-328

* Bretherton L, Kamalanathan M, Genzer J, Hillhouse J and others (2019) Response of natural phytoplankton communities exposed to crude oil and chemical dispersants during a mesocosm experiment. Aquat Toxicol 206: 43-53

Brooks GR, Larson RA, Schwing PT, Romero I and others (2015) Sedimentation pulse in the NE Gulf of Mexico following the 2010 DWH blowout. PLOS ONE 10:e0132341

* Burd AB, Jackson GA (2009) Particle aggregation. Annu Rev Mar Sci 1:65-90

Crocker KM, Passow U (1995) Differential aggregation of diatoms. Mar Ecol Prog Ser 117:249-257

* Daly KL, Passow U, Chanton J, Hollander D (2016) Assessing the impacts of oil-associated marine snow formation and sedimentation during and after the Deepwater Horizon oil spill. Anthropocene 13:18-33

*Dilling L, Alldredge AL (2000) Fragmentation of marine snow by swimming macrozooplankton: a new process impacting carbon cycling in the sea. Deep Sea Res I 47: 1227-1245

พ Dilling L, Brzezinski MA (2004) Quantifying marine snow as a food choice for zooplankton using stable silicon isotope tracers. J Plankton Res 26:1105-1114

* Dilling L, Wilson J, Steinberg D, Alldredge AL (1998) Feeding by the euphausiid Euphausia pacifica and the copepod Calanus pacificus on marine snow. Mar Ecol Prog Ser 170:189-201

* Dissanayake AL, Burd AB, Daly KL, Francis S, Passow U (2018a) Numerical modeling of the interactions of oil, marine snow, and riverine sediments in the ocean. J Geophys Res Oceans 123:5388-5405

Dissanayake AL, Gros J, Socolofsky SA (2018b) Integral models for bubble, droplet, and multiphase plume dynamics in stratification and cross flow. Environ Fluid Mech 18:1167-1202

*Doyle SM, Whitaker EA, De Pascuale V, Wade TL and others (2018) Rapid formation of microbe-oil aggregates and changes in community composition in coastal surface water following exposure to oil and the dispersant Corexit. Front Microbiol 9:689

Engel A, Passow U (2001) Carbon and nitrogen content of transparent exopolymer particles (TEP) in relation to their Alcian Blue adsorption. Mar Ecol Prog Ser 219: $1-10$ 
Engel A, Schartau M (1999) Influence of transparent exopolymer particles (TEP) on sinking velocity of Nitzschia closterium aggregates. Mar Ecol Prog Ser 182: 69-76

Fisher CR, Montagna PA, Sutton T (2016) How did the Deepwater Horizon oil spill impact deep-sea ecosystems? Oceanography (Wash DC) 29:182

French-McCay DP, Jayko K, Li Z, Horn M and others (2015) Modeling oil fate and exposure concentrations in the deepwater plume and rising oil resulting from the Deepwater Horizon oil spill. Technical reports for Deepwater Horizon water column injury assessment. Project No. 2011-144. RPS ASA, South Kingstown, RI. DWH-AR0285 776. https://www.doi.gov/deepwaterhorizon/adminrecord

French-McCay DP, Li Z, Horn M, Crowley D, Spaulding ML, Mendelsohn D, Turner C (2016) Modeling oil fate and subsurface exposure concentrations from the Deepwater Horizon oil spill. In: Proc $39^{\text {th }}$ Arctic and marine oilspill program (AMOP) technical seminar. Environment and Climate Change Canada, Ottawa, p 115-150

French-McCay DP, Horn M, Li Z, Jayko K, Spaulding ML, Crowley D, Mendelsohn D (2018) Modeling distribution, fate, and concentrations of Deepwater Horizon oil in subsurface waters of the Gulf of Mexico. In: Stout SA, Wang Z (eds) Oil spill environmental forensics case studies. Elsevier, Oxford, p 683-735

Gärdes A, Iversen MH, Grossart HP, Passow U, Ullrich M (2011) Diatom associated bacteria are required for aggregation of Thalassiosira weissflogii. ISME J 5: 436-445

Gong Y, Zhao X, Cai Z, O'Reilly SE, Hao X, Zhao D (2014) A review of oil, dispersed oil and sediment interactions in the aquatic environment: influence on the fate, transport and remediation of oil spills. Mar Pollut Bull 79:16-33

Gros J, Reddy C, Nelson R, Socolofsky S, Arey J (2016) Simulating gas-liquid-water partitioning and fluid properties of petroleum under pressure: implications for deepsea blowouts. Environ Sci Technol 50:7397-7408

Gros J, Socolofsky SA, Dissanayake AL, Jun I and others (2017) Petroleum dynamics in the sea and influence of subsea dispersant injection during Deepwater Horizon. Proc Natl Acad Sci USA 114:10065-10070

Guillard RRL (1975) Culture of phytoplankton for feeding marine invertebrates. In: Smith WL, Chanley MH (eds) Culture of marine invertebrate animals. Springer, Boston, MA, p 29-60

Hamm CE (2002) Interactive aggregation and sedimentation of diatoms and clay-sized lithogenic material. Limnol Oceanogr 47:1790-1795

* Hansen JLS, Timm U, Kiørboe T (1995) Adaptive significance of phytoplankton stickiness with emphasis on the diatom Skeletonema costatum. Mar Biol 123:667-676

Hu CM, Weisberg RH, Liu YG, Zheng LY and others (2011) Did the northeastern Gulf of Mexico become greener after the Deepwater Horizon oil spill? Geophys Res Lett 38:L09601

Hung CC, Santschi PH (2001) Spectrophotometric determination of total uronic acids in seawater using cationexchange separation and pre-concentration by lyophilization. Anal Chim Acta 427:111-117

Iversen MH, Ploug H (2010) Ballast minerals and the sinking carbon flux in the ocean: carbon-specific respiration rates and sinking velocity of marine snow aggregates. Biogeosciences 7:2613-2624

Jackson GA (1990) A model of the formation of marine algal flocks by physical coagulation processes. Deep Sea Res A 37:1197-1211

Jackson GA (1995) TEP and coagulation during a mesocosm experiment. Deep Sea Res II 42:215-222

Jackson GA (2005) Coagulation theory and models of oceanic plankton aggregation. In: Droppo I, Leppard G, Liss S, Milligan T (eds) Flocculation in natural and engineered environmental systems. CRC Press, Boca Raton, FL, p 284-305

Kiørboe T, Lundsgaard C, Olesen M, Hansen JLS (1994) Aggregation and sedimentation processes during a spring phytoplankton bloom: a field experiment to test coagulation theory. J Mar Res 52:297-323

Kiørboe T, Hansen J, Alldredge AL, Jackson G and others (1996) Sedimentation of phytoplankton during a spring diatom bloom: rates and mechanisms. J Mar Res 54: 1123-1148

Kowalewska G (1999) Phytoplankton-the main factor responsible for transport of polynuclear aromatic hydrocarbons from water to sediments in the southern Baltic ecosystem. ICES J Mar Sci 56:219-222

* Ladd TM, Bullington JA, Matson PG, Kudela RM, IglesiasRodríguez MD (2018) Exposure to oil from the 2015 Refugio spill affects phytoplankton physiology and increases the toxin content of a common coastal harmful algal bloom species, Pseudo-nitzschia australis, and the ubiquitous coccolithophore, Emiliania huxleyi. Mar Ecol Prog Ser 603:61-78

* Larson RA, Brooks GR, Schwing PT, Holmes CW, Carter SR, Hollander DJ (2018) High-resolution investigation of event driven sedimentation: northeastern Gulf of Mexico. Anthropocene 24:40-50

Lee K (2002) Oil-particle interactions in aquatic environments: influence on the transport, fate, effect and remediation of oil spills. Spill Sci Technol Bull 8:3-8

Lee RF, Anderson JW (1977) Fate and effect of naphthalenes: controlled ecosystem pollution experiment. Bull Mar Sci 27:127-134

* Lee RF, Gardner WS, Anderson JW, Blaylock JW, BarwellClarke J (1978) Fate of polycyclic aromatic hydrocarbons in controlled ecosystem enclosures. Environ Sci Technol 12:832-838

Lee K, Wong CS, Cretney WJ, Whitney FA, Parsons TR, Lalli C, Wu J (1985) Microbial response to crude oil and Corexit 9527: SEAFLUXES enclosure study. Microb Ecol 11:337-351

Lee K, Li Z, King T, Kepkay P, Boufadel MC, Venosa AD, Mullin JV (2008) Effects of chemical dispersants and mineral fines on partitioning of petroleum hydrocarbons in natural seawater. IOSC Proc 2008:633-638

Kewan MD, Warden A, Dias RF, Lowry ZK and others (2014) Asphaltene content and composition as a measure of Deepwater Horizon oil spill losses within the first 80 days. Org Geochem 75:54-60

* Logan BE, Passow U, Alldredge AL, Grossart HP, Simon M (1995) Rapid formation and sedimentation of large aggregates is predictable from coagulation rates (halflives) of transparent exopolymer particles (TEP). Deep Sea Res II 42:203-214

* Lubecki L, Kowalewska G (2010) Distribution and fate of polycylic aromatic hydrocarbons (PAHs) in recent sediments from the Gulf of Gdansk (SE Baltic). Oceanologia 52:669-703

*Mari X, Passow U, Migon C, Burd AB, Legendre L (2017) Transparent exopolymer particles: effects on carbon 
cycling in the ocean. Prog Oceanogr 151:13-37

Mopper K, Zhou J, Ramana KS, Passow U, Dam HG, Drapeau DT (1995) The role of surface-active carbohydrates in the flocculation of a diatom bloom in a mesocosm. Deep Sea Res II 42:47-73

Morris DL (1948) Quantitative determination of carbohydrates with Dreywood's anthrone reagent. Science 107:254-255

National Academies of Sciences, Engineering, and Medicine (2016) Spills of diluted bitumen from pipelines: a comparative study of environmental fate, effects, and response. The National Academies Press, Washington, DC

Nelson RK, Aeppli C, Arey JS, Chen H and others (2016) Applications of comprehensive two-dimensional gas chromatography $(\mathrm{GC} \times \mathrm{GC})$ in studying the source, transport, and fate of petroleum hydrocarbons in the environment. In: Stout SA, Wang Z (eds) Standard handbook oil spill environmental forensics, $2^{\text {nd }}$ edn. Academic Press, Boston, MA, p 399-448

North EW, Adams EE, Thessen AE, Schlag Z and others (2015) The influence of droplet size and biodegradation on the transport of subsurface oil droplets during the Deepwater Horizon spill: a model sensitivity study. Environ Res Lett 10:024016

Özhan K, Miles S, Gao H, Bargu S (2014) Relative phytoplankton growth responses to physically and chemically dispersed South Louisiana sweet crude oil. Environ Monit Assess 186:3941-3956

Parsons ML, Turner RE, Overton EB (2014) Sediment-preserved diatom assemblages can distinguish a petroleum activity signal separately from the nutrient signal of the Mississippi River in coastal Louisiana. Mar Pollut Bull 85: 164-171

* Parsons ML, Morrison W, Rabalais NN, Turner RE, Tyre KN (2015) Phytoplankton and the Macondo oil spill: a comparison of the 2010 phytoplankton assemblage to baseline conditions on the Louisiana shelf. Environ Pollut 207: 152-160

Passow U (2002) Transparent exopolymer particles (TEP) in aquatic environments. Prog Oceanogr 55:287-333

* Passow U (2004) Switching perspectives: Do mineral fluxes determine particulate organic carbon fluxes or vice versa? Geochem Geophys Geosyst 5(4):1-5

* Passow U (2016) Formation of rapidly-sinking, oil-associated marine snow. Deep Sea Res II 129:232-240

* Passow U, Alldredge AL (1995) A dye-binding assay for the spectrophotometric measurement of transparent exopolymer particles (TEP). Limnol Oceanogr 40:1326-1335

* Passow U, De La Rocha CL (2006) Accumulation of mineral ballast on organic aggregates. Global Biogeochem Cycles 20:GB1013

Passow U, Ziervogel K (2016) Marine snow sedimented oil released during the Deepwater Horizon spill. Oceanography (Wash DC) 29:118-125

Passow U, Alldredge AL, Logan BE (1994) The role of particulate carbohydrate exudates in the flocculation of diatom blooms. Deep Sea Res I 41:335-357

Passow U, Ziervogel K, Asper V, Diercks A (2012) Marine snow formation in the aftermath of the Deepwater Horizon oil spill in the Gulf of Mexico. Environ Res Lett 7: 035301

Passow U, Sweet J, Quigg A (2017) How the dispersant Corexit impacts the formation of sinking marine oil snow. Mar Pollut Bull 125:139-145
Ploug H, Terbrüggen A, Kaufmann A, Wolf-Gladrow D, Passow U (2010) A novel method to measure particle sinking velocity in vitro, and its comparison to three other in vitro methods. Limnol Oceanogr Methods 8:386-393

Quigg A, Passow U, Chin WC, Xu C and others (2016) The role of microbial exopolymers in determining the fate of oil and chemical dispersants in the ocean. Limnol Oceanogr Lett 1:3-26

Reed M, Daling PS, Brakstad OG, Singsaas I, Faksness LG, Hetland B, Ekrol N (2000) OSCAR2000: a multi-component 3-dimensional oil spill contingency and response model. In: Proc $23^{\text {rd }}$ Arctic and marine oilspill program (AMOP) technical seminar. Environment Canada, Ottawa, p 663-952

Romero IC, Schwing PT, Brooks GR, Larson RA and others (2015) Hydrocarbons in deep-sea sediments following the 2010 Deepwater Horizon blowout in the northeast Gulf of Mexico. PLOS ONE 10:e0128371

* Romero IC, Toro-Farmer G, Diercks AR, Schwing $P$, Muller-Karger F, Murawski S, Hollander D (2017) Large-scale deposition of weathered oil in the Gulf of Mexico following a deep-water oil spill. Environ Pollut 228:179-189

* Schwing PT, O'Malley BJ, Hollander DJ (2018) Resilience of benthic foraminifera in the northern Gulf of Mexico following the Deepwater Horizon event (2011-2015). Ecol Indic 84:753-764

* Smetacek VS (1985) Role of sinking in diatom life-history cycles: ecological, evolutionary, and geological significance. Mar Biol 84:239-251

Smith PK, Krohn RI, Hermanson GT, Mallia AK and others (1985) Measurement of protein using bicinchoninic acid. Anal Biochem 150:76-85

* Smith RJ (2009) Use and misuse of the reduced major axis for line-fitting. Am J Phys Anthropol 140:476-486

Spaulding ML, Howlett E, Anderson E, Jayko K (1992) OILMAP: a global approach to spill modeling. In: Proc $15^{\text {th }}$ Arctic and marine oilspill program (AMOP) technical seminar. Environment Canada, Ottawa, p 15-21

Stout SA (2015a) Bulk chemical and physical properties of fresh and weathered Macondo crude oil. Technical report to the Trustees in support of the pDARP. NewFields Environmental Forensics Practice, Rockland, MA

Stout SA (2015b) Distribution and weathering of Macondo oil stranded on shorelines in 2010 based on chemical fingerprinting. NewFields Environmental Forensics Practice, Rockland, MA

Stout SA (2016) Refugio beach oil spill NRDA investigation: Trustees forensics oil source analysis. Report to NOAA/ CA-DFW. NewFields Environmental Forensics Practice, Rockland, MA

* Strauch S, Herminghaus S (2012) Wet granular matter: a truly complex fluid. Soft Matter 8:8271-8280

* Valentine DL, Fisher GB, Bagby SC, Nelson RK, Reddy CM, Sylva SP, Woo MA (2014) Fallout plume of submerged oil from Deepwater Horizon. Proc Natl Acad Sci USA 111: 15906-15911

* Verdugo P, Santschi P (2010) Polymer dynamics of DOC networks and gel formation in seawater. Deep Sea Res II 57 : 1486-1493

Wade TL, Sweet ST, Sericano JL, Guinasso N Jr and others (2011) Analyses of water samples from the Deepwater Horizon oil spill: documentation of the subsurface plume. Geophys Monogr Ser 195:77-82 
Wade TL, Morales-McDevitt M, Bera G, Shi D and others (2017) A method for the production of large volumes of WAF and CEWAF for dosing mesocosms to understand Marine Oil Snow formation. Heliyon 3:e00419

Washburn TW, Reuscher MG, Montagna PA, Cooksey C, Hyland JL (2017) Macrobenthic community structure in the deep Gulf of Mexico one year after the Deepwater Horizon blowout. Deep Sea Res I 127:21-30

White FM (1991) Viscous fluid flow, $2^{\text {nd }}$ edn. McGraw Hill, New York, NY

Winters H, Chong TH, Fane AG, Krantz W, Rzechowicz M, Saeidi N (2016) The involvement of lectins and lectinlike humic substances in biofilm formation on RO membranes - Is TEP important? Desalination 399:61-68

Wirth M, Passow U, Jeschek J, Hand I, Schulz-Bull DE (2018) Partitioning of oil compounds into marine oil snow: insights into prevailing mechanisms and dispersant effects. Mar Chem 206:62-73

Xu C, Zhang S, Chuang Cy, Miller EJ, Schwehr KA, Santschi PH (2011) Chemical composition and relative hydrophobicity of microbial exopolymeric substances (EPS) isolated by anion exchange chromatography and their actinide-binding affinities. Mar Chem 126:27-36

Xu C, Zhang S, Beaver M, Lin P and others (2018) The role of microbially-mediated exopolymeric substances (EPS) in regulating Macondo oil transport in a mesocosm experiment. Mar Chem 206:52-61

Editorial responsibility: Katherine Richardson, Copenhagen, Denmark; Ronald Kiene, Mobile, Alabama, USA
Yan B, Passow U, Chanton J, Nöthig EM and others (2016) Sustained deposition of contaminants from the Deepwater Horizon spill. Proc Natl Acad Sci USA 113:E3332-E3340

Khang S, Jiang Y, Chen CS, Spurgin J and others (2012) Aggregation, dissolution, and stability of quantum dots in marine environments: importance of extracellular polymeric substances. Environ Sci Technol 46:8764-8772

Zhao L, Boufadel MC, Geng X, Lee K, King T, Robinson B, Fitzpatrick F (2016) A-DROP: a predictive model for the formation of oil particle aggregates (OPAs). Mar Pollut Bull 106:245-259

* Zhao L, Boufadel MC, Katz J, Haspel G, Lee K, King T, Robinson B (2017) A new mechanism of sediment attachment to oil in turbulent flows: projectile particles. Environ Sci Technol 51:11020-11028

* Zheng L, Yapa PD, Chen FH (2003) A model for simulating deepwater oil and gas blowouts - Part I: Theory and model formulation. J Hydraul Res 41:339-351

Khou J, Mopper K, Passow U (1998) The role of surfaceactive carbohydrates in the formation of transparent exopolymer particles by bubble adsorption of seawater. Limnol Oceanogr 43:1860-1871

Zick AA (2013) Equation-of-state fluid characterization and analysis of the Macondo reservoir fluids. Expert report TREX-011490R prepared on behalf of the United States as evidence in the US v. BP Exploration \& Production, Inc., et al. case. Zick Technologies, Portland, OR

Submitted: August 31, 2018; Accepted: January 31, 2019

Proofs received from author(s): February 25, 2019 